\title{
Rosalía de Castro e influencias. Un diálogo entre o centro e a periferia
}

\author{
Rosalía de Castro and Influences. A Dialogue between the \\ Center and the Periphery
}

ViCENTE VÁZQUEZ VIDAL

vxente@hotmail.com

Recibido: enero 2019. Aceptado: febrero 2019

\begin{abstract}
Resumo: Rosalía de Castro (1837-1885) representa un papel canónico tanto na literatura castelá como na galega. Propomos unha visión da súa figura autoral á luz da Teoría dos Polisistemas Literarios formulada por Itamar Even-Zohar, a cal entende a tradución literaria como un factor fundamental do concepto de influencia. Acto seguido, presentaremos un exercicio de literatura comparada onde poremos en relación as obras de Rosalía coas doutros autores da sua época, o que nos dará una mellor idea do seu papel, tanto nas relacións centro-periferia literarias, como na configuración dunha literatura europea. Veremos como a autora bebe de fontes literarias insospeitadas. Por último, examinaremos a súa obra de para ver como Rosalía escapa de calquera clasificación tradicional posible, sendo o seu espazo de acción, precisamente, a fronteira.
\end{abstract}

Palabras chave: literatura galega, século XIX, Rosalía de Castro, influencias, polisistemas, centro e periferia.

Abstract: Rosalía de Castro (1837-1885) holds a canonic role in both Castilian and Galician literature. A vision of her authorial identity is proposed in terms of Itamar Even-Zohar's Polysystem Theory, which understands literary translation as a fundamental factor in the concept of influence. Subsequently, an exercise in comparative literature will be presented in which de Castro's works are examined in relation to those of other authors of her time, which will shed light on the nature of her role, both in center-periphery relations and in the constitution of a European literature. De Castro's unsuspected sources of literary inspiration will then be discussed. Lastly it will be considered how de Castro's body of work has escaped from any traditional classification whatsoever, as its sphere of action is, for all intents and purposes, the border space.

Key words: Galician literature, 19th century, Rosalía de Castro, influences, polysystems, center and periphery 


\section{I.- AS INFLUENCIAS DE ROSALÍA}

\section{1.- A literatura en castelán}

Rosalía de Castro (1837-1885) publica as súas primeiras obras nun mundo xa sorprendentemente globalizado. Este fenómeno, lonxe de ser unha cuestión dos tempos nos que vivimos, apararece, cando menos no literario, xa nas primeiras década do XIX. Ligado a este aspecto, atopamos conceptos como a Weltliteratur de Goethe, á luz da cal o poeta teutón proclamaba a chegada dunha literatura mundial. En Rosalía de Castro, tal e como veremos máis adiante, este pulso entre a aldea e o mundo global pode verse en varios estratos da súa obra e figura. Lonxe das explicacións excesivamente biograficistas que xe fixeron da autora e, tamén, da falta de investigacións sobre as influencias que durante décadas houbo no campo dos estudos rosalianos, este artigo leva por encomenda iluminar aqueles aspectos referentes ao acceso da autora de Padrón ás obras universais da súa época, para desbotar a idea errada da Rosalía rural e doméstica convertida en autora e erudita case por arte de maxia.

Para un mellor entendemento do concepto de influencia, a Teoría dos Polisistemas, unha das máis actuais e completas, das teorías denominadas sistémicas, que explica os procesos de influencia literaria. Esta teoría entende as diferentes literaturas de forma dinámica nas que as mesmas se interrelacionan unhas ás outras grazas a procesos como a tradución, que permiten exportar elementos literarios duns sistemas a outros. Estes polisistemas literarios estarían formados por varias literaturas, algunhas delas centrais e outras periféricas que, polo xeral, están nun estado continuo de intercambio de elementos literarios, sexan estes últimos, obras, modelos e mesmos xéneros (Even-Zohar 1995: 59-65). No polisistema literario do Romanticismo europeo, os sistemas alemán, francés e inglés mantiñan unha posición central, é dicir, exportaban elementos literarios a outros sistemas periféricos. Como veremos, as nocións en lingua francesa de Rosalía de Castro permitíronlle ter acceso a obras (orixinais ou traducidas) que moitos dos seus contemporáneos pode que non tivesen chegado a coñecer.

O cerne deste artigo consiste, pois, en examinar como Rosalía bebe doutros sistemas literarios europeos, para posteriormente trasladar elementos ao seu campo literario de acción. Para poder establecer de que autores toma Rosalía as súas influencias e onde as devolve, é preciso un labor comparatista que poña en relación os textos rosalianos con outras obras do momento.

Aproveitando esta dialéctica entre entre o central e o peiférico, propomos nunha última parte deste artigo examinar outros factores da figura autoral de Rosalía para ver con máis claridade o seu papel fronteirizo entre a periferia e a centralidade, non só entendidos como campos literarios, senón como un binomio que atravesa boa parte da súa vida e da súa produción literaria. Con isto, obteremos unha visión máis axeitada da autora. Este artigo pretende, pois, dar resposta a dúas cuestións principais: quen era, e que leu Rosalía de Castro? Comecemos pola máis sinxela das dúas. 


\section{2.- As influencias: que leu Rosalía?}

Cómpre comezar este punto resaltando a importancia da lectura como ferramenta cradora de identidade autoral. Non se pode entender o proceso de creación literaria de forma illada, pois un autor rara vez se bota a escribir sen antes ter lido. Chegados a este punto, habemos ver como as lecturas de Rosalía foron relevantes para a construción dunha voz moderna, propia e acorde cos tempos. Propomos pois, a continuación unha análise comparativa da obra rosaliana para responder a unha das cuestións capitais que visa descubrir este artigo: que leu Rosalía?

O lector pode imaxinar que un exercicio comparatista desta envergadura ultrapasa as dimensións deste ensaio, con todo, preténdese nas seguintes páxinas desenterrar os principais lazos que unen a obra rosaliana co resto das principais obras da literatura europea do momento. Por cuestións de espazo, este artigo centrarase especialmente, aínda que non en exclusiva, no estudo das influencias da súa primeira novela: La hija del mar (1859).

\section{3.- Relacións coa literatura castelá}

Se hai unha obra en que Rosalía presume sen pudores sobre os seus coñecementos literarios, esta é a súa primeira obra narrativa La hija del mar (1859). Algúns autores, entre eles, Mayoral, chegan a afirmar que estas citas e alusión que Rosalía fornece en tantas ocasións, poden ser ser debidos a que á voz autoral «se le nota a veces cierta pedantería juvenil, que se manifiesta en la ostentación de sus conocimientos mediante comparaciones cultas traídas por los pelos» (Mayoral 1986: 343).

As relacións da obra de Rosalía de Castro cos autores da literatura castelá son varias e complexas. Na súa maioría, en Rosalía atopamos referencias a autores contemporáneos seus, na súa maioría, románticos. José Zorrilla, por exemplo, aparece citado directa ou indirectamente en varias ocasións. No inicio do capítulo IV de La hija del mar atopamos a primeira delas, unha cita pertencente ao Don Juan Tenorio, obra publicada en 1844, máis de dúas décadas antes da publicación da primeira novela de Rosalía. Ademais de compartiren certos recursos temáticos (a deshonra dunha moza pura e virtuosa), posibelmente a presenza da cita «¿Quién de tus gracias no se enamora? / Hija del aire, ¿quién no te adora?» (Castro 2005: 115), reforza o sentido e a intención deste capítulo, dedicado a presentar a Esperanza, personaxe protagonista e muller de virtudes e beleza sen parangón. Reparemos, ademais, na correlación entre o apelativo da cita de Zorrilla, «Hija del aire» e no propio título desta novela de Rosalía. Cabe mencionar, que tamén o capítulo XVII abre cunha cita deste autor.

De seguirmos o rastro do Tenorio nesta obra de Rosalía, chegaremos ao capítulo VIII onde a clásica metáfora das bágoas como perlas que convidan a ser bebidas nos remite á seguinte pasaxe do Tenorio: «Y esas dos líquidas perlas / que se desprenden tranquilas / de tus radiantes pupilas / convidándome a 
beberlas, / evaporarse a no verlas / de si mismas al calor [...]» (Zorrilla 2003: 148). Contrastemos esta pasaxe con estoutra do anteriomente citado capítulo de La hija del mar:

Escucharon largo tiempo, como sumidos en la dulcísima percepción de la melodía, pero al fin los ojos de la mujer se llenaron de lágrimas y los del hombre de una voluptuosidad contagiosa y ardiente que, reflejándose en el rostro de ella, secó su llanto e hizo cubrir sus mejillas con el carmín delicado de ese rubor próximo a extinguirse en la palidez de una emoción mil veces más vehemente que la más abrasadora fiebre. (Castro 2005: 170)

Despois dunha lectura atenta da obra rosaliana comezamos a decatarnos, como se está a demostrar, que esta autora, malia escribir desde a periferia dun Estado, estaba atenta ás novidades literarias dos seus contemporáneos. É moi revelador que neste texto de Rosalía que estamos a tratar, se atopen varias referencias a José de Espronceda, un autor que podemos considerar plenamente romántico, e ademais un dos moitos que tivo que exiliarse: estivo en Portugal, Inglaterra e Francia, o cal nos dá bastantes pistas á hora de seguir o rastro do Romanticismo europeo que chegou a Rosalía. No capítulo XIV de La hija del mar, un capítulo crucial non só para o desenvolvemento da novela, senón tamén cheo de referencias literarias aos compoñentes do elenco das lecturas de Rosalía; atopamos xunto cunha cita de Espronceda, un exemplo máis do xa coñecido topo rosaliano do esquecemento após a morte:

Pero ¡qué amargos eran sus recuerdos! Su enferma imaginación no hacía más que atormentarla con el tenaz recuerdo de Fausto..., le veía inmóvil, clavando en ella la fría y vidriosa mirada, silencioso...,

Hay siempre en derredor del cuerpo muerto una tan honda soledad y olvido,

como ha dicho Espronceda, que aun el más ignorante respeto al horrible misterio de la muerte no puede sufrir sin un secreto terror la vista de un cadáver. (Castro 2005: 238)

A pertinencia desta cita de Espronceda (en cursiva no texto que vimos de citar) é, sen lugar a dúbida, moi discutíbel. A necesidade desta cita, ao nosos parecer, non reside en si mesma, senón no capital simbólico que unha cita de Espronceda podería dar a unha escritora novel como era a Rosalía de 22 anos que acababa de publicar a súa primeira novela. Resulta moi interesante facer unha distinción entre as citas de forma directa, mencionando o autor e mesmo a obra, e aquilo ao que Rosalía fai referencia, evidenciando claramente unha influencia ou unha lectura, mais sen chegar a dar nomes ou obras. Parécenos que tal distinción marca o camiño entre os autores aos que Rosalía considera como influencia, "pais literarios", dalgún xeito, e aqueles aos que ela, sexa pola razón que for, non lle interesa que a relacionen. Esta distinción, como dicimos, resúltanos de moito interese, con todo, quedará para novas investigacións, pois ultrapasaría as dimensións deste ensaio. 
Por último, antes de pasar a outro autor, gustaríanos chamar a atención sobre as semellanzas entre as últimas liñas desta novela de Rosalía que estamos a tratar e o episodio co que comeza o poema narrativo de Espronceda El estudiante de Salamanca:

Súbito rumor de espadas / cruje y un jay! se escuchó; / un ay moribundo, un ay / que penetra el corazón, / que hasta los tuétanos hiela / y da al que lo oyó temblor. / Un ¡ay! de alguno que al mundo / pronuncia el último adiós. (Espronceda 1984: 315)

Comparemos esta concatenación de «ay» no seguinte parágrafo que pon fin a La hija del mar:

Un ¡ay! prolongado y lastimero, último acento que lanza el moribundo al despedirse de este mundo, un ¡ay! desgarrador nacido de las esencias más amargas y de los pesares más intensos [...] (Castro 2005: 321)

Se diciamos que Espronceda nos daría pistas sobre os derroteiros europeos polos que transcorreron elementos literarios que atopamos na obra de Rosalía, debémoslle posibelmente ao romántico Enrique Gil y Carrasco o achegamento da novela de carácter histórico ao estilo do escocés Walter Scott. A novela máis celebrada de Gil y Carrasco, El señor de Bembibre (1844), aportaríalle a Rosalía unha das convencións máis singulares da novela histórica: o carácter dos personaxes equipárase con elementos acuáticos. Isto é, como é obvio, unha característica xeral do Romanticismo: a identificación do estado de ánimo do personaxe coa natureza. Con todo, a novidade que aporta esta convención da novela histórica fundada por Walter Scott reside, precisamente, na mutabilidade da auga. Tanto nas novelas de Scott como en El señor de Bembibre, as características das augas dos lagos serven a cotío para caracterizar o interior psicolóxico dos personaxes. É preciso chamar aquí atención sobre a enorme importancia que ten o mar nesta novela de Rosalía, importancia que case con certeza foi buscada pola autora. Hai, precisamente, unha cita de Lord Byron con que a autora inicia ao capítulo X. Permítasenos facer un inciso nesta relación de autores casteláns e incluír aquí a seguinte de Lord Byron, que como ben se pode ver, dá conta de forma extraordinaria da relación entre natureza e espírito romántico:

Comme les flots capricieux de l'Océan, les sentiments humains / ont leur flux et leur reflux, qui voudrait se fier à une âme / qui troublent toujours d'orageuses passions? ${ }^{1}$ (Castro 2005: 195)

Esta cita, que como vimos dicindo, resume unha das características fundamentais do pensamento romántico, chega a Rosalía grazas aos seus coñecemen-

1 «Como as ondas caprichosas do Océano, os sentimentos humanos teñen o seu fluxo e refluxo; quen querería fiarse dunha alma sempre turbada por tormentosas paixóns?» Tradución propia. 
tos de francés. Rosalía tivo unha educación ampla e interdisciplinar, posibelmente moito mellor ca calquera tipo de educación que recibían as mozas da súa condición social na súa época. Os seus estudos de música (sabemos que tocaba guitarra e piano) foron complementadas coa práctica da lectura en francés, o que lle abriu as portas de boa parte da literatura europea e mundial. É deste xeito, a través do francés, como Rosalía entra en contacto con autores como Byron, para os que posibelmente non houbese unha tradución ao castelán. Nesta dirección apuntaranse nos vindeiros capítulos outras vías de estudo no referente á importancia que tivo o francés na configuración do imaxinario literario da autora.

Seguindo con esta relación de autores e influencias casteláns, non podemos deixar de mencionar aquí a que sexa posibelmente o autor lírico máis canonizado do romanticismo español. Gustavo Adolfo Bécquer nace, curiosamente, un ano antes de Rosalía e os paralelismos vitais e literarios entre ambos non son poucos. Sobre a existencia dunha relación persoal de amizade entre ambos non hai evidencias probadas, mais o que si se sabe é que Bécquer puido ter coincidido con Murguía nalgún dos xornáis en que ambos traballaron en Madrid. Alén das relacións persoais, tras unha lectura da obra rosaliana, non é difícil atopar referencias ou similitudes con poemas célebres do sevillano: «La languidez de su mirada y las largas pestañas que hacian sombra sobre sus mejillas no bastaban a ocultar el rayo brillante que despedía su pupila oscura y fosforescente.» (Castro 2005: 84-85), o tema dos ollos, ben como elemento escuro, demoníaco ou de atracción, ou ben como reflexo do interior, da bondade e a beleza dunha persoa é un tema repetidamente tratado por ámbolos dous autores. Bécquer publica en 1861 unha lenda titulada "Los ojos verdes" no xornal El contemporáneo de Madrid.

Para rematar con este inventario de autores e obras casteláns, é necesario reparar en Fernán Caballero, nome de pluma da autora Cecilia Böhl de Faber, diametralmente oposta a Rosalía de Castro, malia a súa condición de muller escritora. Fernán Caballero estaba, se callar, política e socialmente, máis preto da figura de Pardo Bazán, en relación a cuestións como a defensa das clases acomodadas, o catolicismo, o nacionalismo español, etc. A relación entre ambas escritoras é complexa. Roslía dedícalle Cantares gallegos:

\section{A FERNÁN CABALLERO}

Señora:

Por ser mujer y autora de unas novelas hacia las cuales siento la más profunda simpatía, dedico a usted este pequeño libro. Sirva él para demostrar a la autora de La Gaviota y de Clemencia el grande aprecio que le profeso, entre otras cosas, por haberse apartado algún tanto, en las cortas páginas en que se ocupó de Galicia, de las vulgares preocupaciones con que se pretende manchar mi país.

Santiago, 17 de mayo de 1863. (Castro 1993: 485)

O sentido desta dedicatoria é, dalgún xeito, algo estraño. Sabemos que en 1859 Fernán Caballero publica Cuentos y poesías populares andaluces, obra 
con un gran número de similitudes cos Cantares, e posibelmente, fonte de inspiración para a publicación dos mesmos por parte de Rosalía ${ }^{2}$, sobrenténdese aquí, pois, unha certa complicidade entre as autoras, chegando Rosalía inclusive a expresar a súa admiración por Fernán Caballero. Ademais desta razón, na dedicatoria pode lerse outra: a ausencia nas obras da andaluza das «vulgares preocupaciones» con que se cualificaba Galicia na literatura do momento. Sabemos que a denominada lenda negra coa que se caracterizaba á comunidade e aos seus habitantes dun modo pexorativo, burlesco ou denigrante. Esta imagoloxía estivo presente na literatura española desde o Século de Ouro e, polo visto, continuaba moi presente na época de Rosalía con preconceptos e imaxes referentes á incultura, atraso e modais brutos dos galegos. Estudos sobre a imaxe de Galicia e os galegos na literatura castelá poden Rosalía, recoñece e agradécelle, pois, a Fernán Caballero o afastarse deses estereotipos nas súas descricións de Galicia. Hai, con todo, certas dúbidas no referente a intención desta dedicatoria, pois a andaluza si tería feito uso destes preconceptos nas obras referidas por Rosalía na dedicatoria ${ }^{3}$. Estamos, pois, ante unha vinganza literaria?

A relación entre as autoras, como vimos dicindo, foi complexa. Grazas aos poucos escritos que se conservan (correspondencia privada entre as autoras ${ }^{4}$ ), sabemos que se enviaron exemplares dedicados das súas obras en varias ocasións, seguido das apreciacións e xuizos após a lectura. Despois desta dedicatoria a Fernán Caballero, a autora andaluza responde con halagos á obra de Rosalía. Aquí aparece, por exemplo, o epíteto tantas veces repetido para describir a Rosalía: "ruiseñor de Galicia", lle chama Caballero nunha carta onde louva os seus poemas: «Nunca Señora he leido poesias de mas profunda sensivilidad de

2 Ademais desta obra de Caballero, Rosalía menciona no prólogo dos Cantares outra obra: «O libro dos Cantares de don Antonio Trueba, que me inspirara e dera alento pra levar a cabo este traballo, pasa polo meu pensamento como un remorso, e casi sin asoman as bágoas ós meus ollos ó pensar como Galicia se levantaría hastra o lugar que lle corresponde» (Castro 1993: 488). El libro de los cantares, publicado en 1852 e da autoría do biscaíño Antonio de Trueba, preséntase no prólogo de cantares como unha influencia de Rosalía.

3 A investigadora María do Cebreiro Rábade Villar expón neste artigo para o xornal El País algúns dos argumentos polos que Rosalía faría uso do seu "carácter arroutado" e da ironía empregada nesta dedicatoria para, dalgún xeito, vingarse de Fernán Caballero polo desprezo e "superioridade da cultura do sur de España" que se manifesta en moitas das súas obras, entre elas De una en otra ou Un tío en América. Ben é certo que nas obras que Rosalía menciona na dedicatoria, a imaxe que Caballero dá de Galicia, non é todo mala, positiva mesmo, se comparada coas obras que vimos de referir. Para cadrar as pezas deste crebacabezas sería preciso saber, pois, se Rosalía leu antes da publicación de Cantares as obras de Caballero que continúan coa tradición imagolóxica da lenda negra galega, para sabermos con certeza se a dedicatoria de Cantares se trata dunha mostra de cariño e admiración literaria ou, pola contra, de toda unha vinganza literaria e bastante irónica. Este artigo do El País pode lerse en liña baixo na seguinte ligazón <http://ccaa.elpais.com/ ccaa/2012/09/13/galicia/1347566460_335088.html> Consultado o día 03/03/2018.

${ }_{4}$ A correspondencia da que falamos pode consultarse en liña na seguinte ligazón $<$ http:// rosalia.gal/wp-content/uploads/2013/07/NovoExemplarCantaresGallegos.pdf $>$ Consultado o día $03 / 03 / 2018$. 
sentimiento mas real no inspiradas ciertamente por la cabeza pero brotadas del corazon y de un corazon selecto, pues solo tal corazon, siente como V. sabe expresarlo (sic) ${ }^{5}$ mais tamén se mostra o seu incomodo por non ser quen de entender moitas palabras do galego e, quizais o máis interesante para o obxectivo deste traballo, por se queixar tanto do trato que reciben os galegos cando van de xornaleiros ás Castelas, o que Fernán Caballero alixeira alegando que tamén os andaluces reciben un trato semellante no resto de España:

Diré a V. no obstante que me parece injusto la injusticia de que V. se queja y lamenta tocante a su país. Galicia sus hombres, monumentos, marina y antiguedades, ocupan un lugar mui privilegiado en la historia de España y harto mas que otras provincias. Si de los gallegos grotescos é ineptos que salen de su pais para ocupar oficios bajos pero lucrativos en otros, se burlan, recuerde V. que la jactancia y ponderaciones de los andaluces son igualmente un continuo manantial de burlescos chistes, para las demas provincias. ${ }^{6}$

Esta carta está datada do 25 de xaneiro de 1864, meses despois da publicación de Cantares. A correspondencia entre Fernán Caballero e Rosalía parece prolongarse durante o tempo, temos, por exemplo, constancia de que a obra $E l$ caballero de las botas azules (1867) recibiu tamén os eloxios da andaluza. Se volvemos a anterior carta, temos tamén constancia dunha misiva enviada por Rosalía a Murguía na que describe a Fernán Caballero da seguinte forma: «[...] se porta efectivamente como una plebeya, pero se lo perdono. No dudo que es buena, pero imagínate que si tiene, como me supongo, la manía de Ferminita agregada a otras muchas y a una respetable edad, ;de qué modo mirará las cosas! Sábelo Dios, y el efecto que la abra hecho la...» (Castro 1993 II: 605). Aquí acaba a carta de Rosalía, unha das poucas que sobreviviron á queima que se fixo dos seus documentos após a súa morte. É difícil saber a que se refire Rosalía co apelativo "plebeya", mais supoñemos que as palabras que Caballero lle dedicou sobre a esaxeración das súas queixas en Cantares non lle pareceron xustas. O que si sabemos é cal era a manía da citada Ferminita, personaxe da obra El barón (1803) de Fernández de Moratín. Esta personaxe está caracterizada pola súa excesiva sinceridade, xa que non dubida nunca en dicir o que pensa dos outros personaxes, mesmo chegando a ferilos con insultos (Acosta 1990: 417-431).

Cando aparece La hija del mar en 1859 xa apareceran no panorama literario español varias novelas de Fernán Caballero, e a mediados de século incorpóranse outras mulleres como Carolina Coronado, Ángela Grassi, Gertrudis Gómez de Avellaneda, Faustina Sáez de Melgar ou Emilia Serrano, estando todas elas bastante en contacto. Con todo, Rosalía preferiu illarse e manterse á marxe deste movemento de incorporación da muller á vida intelectual do país, según nos indica Montserrat Ribao (Castro 2005: 79).

5 Esta carta de Fernán Caballero atópase trascrita e en liña baixo na páxina da Real Academia Galega na seguinte ligazón: <http://academia.gal/documents/10157/735152/Carta+FernánCaballero+a+Rosal\%C3\%ADaCastro+25-01-1864+transcrita.pdf $>$ Consultado o día 13/02/2018.

6 Idem 


\section{4.- As influencias francesas}

Como xa se dixo, o feito de poder Rosalía ler en francés propiciou que puidese ter acceso, non só a boa parte da literatura francesa, senón tamén a boa parte doutras obras (principalmente inglesas e alemás) que aínda non tiñan tradución para o castelán, o que converteu a Rosalía nunha lectora, en certo modo, avantaxada se a compararmos con outros autores da Península. Dos autores e obras alemáns e ingleses daremos conta noutros capítulos, pois o presente estará dedicado aos autores franceses. Como no anterior capítulo, daremos conta desta relación de autores situándoos nun eixo temporal, de máis antigos até máis modernos.

Un dos primeiros autores aos que Rosalía fai referencia na súa obra é Jacques-Henri Bernardin de Saint-Pierre (1737-1814), citado pola poeta de Padrón como B. Saint-Pierre no capítulo XI de La hija del mar, acompañado da cita: «¿Quién me podrá estorbar que yo la siga?» (Castro 2005: 207). Cómpre dicir que obra de Saint-Pierre á que pertence esta cita é algo que aínda queda por investigar. Sería conveniente localizar esta cita na obra do francés para analizar, principalmente, as relacións desta obra coa da galega. Como parece ter por costume Rosalía, a pertinencia desta cita precisamente neste capítulo poida que nos resulte difícil de atopar. Como xa vimos noutras ocasións, Rosalía empregaba citas con algunha afinidade co narrado no capítulo, mais sen moita máis importancia para a comprensión do texto. Case nos atreveriamos a dicir, como xa formulamos no capítulo anterior, que Rosalía tira partido do capital simbólico dos autores que cita para situarse no campo literario, como se esa fose a súa forma de xustificar a súa pertenza entre autores recoñecidos a través das obras que citou e supostamente leu. A cita coa que comeza o capítulo V, «iSe marchan y yo me quedo!» (Castro 2005: 125) está sacada dalgunha obras de Frédéric Soulié (1800-1847), autor con bastante éxito na súa época, chegando inclusive a igualarse con Dumas ou Balzac, mais practicamente esquecido após a súa morte. O sentido desta cita, como no caso da de Saint-Pierre non é sinxelo de esclarecer.

A seguinte referencia a un autor do polisistema francés é ao diplomático e escritor francés François-René de Chateaubriand, considerado o precursor do movemento romántico en Francia e un verdadeiro exemplo para os autores posteriores, como Victor Hugo, que chegou a declarar «Je veux être Chateaubriand ou rien» (Hovasse 2001: 142). Sospeitamos que a obra René ou les Effets des passions (1802) pode estar tras a inspiración da relación en La hija del mar entre Ansot e a cativa Esperanza, a orfa adoptada por Teresa, esta última a muller con que el tivo un romance e mesmo un fillo que acabou por morrer. Ansot desaparece despois de deixar encinta a Teresa e volve anos máis tarde para acabar apaixonándose por Esperanza (no final descóbrese que ela é súa filla biolóxica) creando un estraño e incestuoso núcleo familiar de paixóns reprimidas e humillacións. Na novela de Chateaubriand, pola contra, a relación establécese entre René, tamén un viaxeiro dos mares, un fuxitivo e a súa irmá Amélie. A inspiración para esta relación flagrante poderíalle vir a Rosalía após a lectura do René, aínda que como 
sabemos as relacións incestuosas son un tópico constante do Romanticismo, comezando posibelmente no Manfredo (1817) de Byron.

Unha pasaxe do primeiro capítulo de La hija del mar remítenos a outro escritor francés que Rosalía parece que leu con atención. Reparemos no seguinte fragmento correspondente ao momento no que os mariñeiros atopan un bebé sobre un cotarelo que sobresae entre as ondas do mar e o traen a terra, feito que causará unha disputa:

Las voces de los descontentos sofocaron las palabras de Lorenzo, y entonces pasó una verdadera tormenta de disputas.

Todos querían para sí aquella hermosa criatura, todos querían ser padres de aquel niño, de aquel hijo del acaso.

Lorenzo, sobre todo, quería alcanzar con gritos y, lo que era mejor todavía, con tinos puños capaces de convencer a un bretón, como diría Dumas, lo que ni sus razones ni la buena voluntad de sus compañeros querían darle. (Castro 2005: 93)

Segundo as aclaracións de Montserrat Ribao para esta edición de La hija del mar que estamos a citar, nas novelas de Dumas, os bretóns aparecían caracterizados estereotipicamente como persoas moi teimudas (Castro 2005: 93). Fixémonos, pois, na identificación que se fai no último parágrafo do carácter de Lorenzo, un dos mariñeiros, que pretende conseguir a golpes o que xa era imposible de conseguir berrando. Rosalía quere deixar claro ao lector implícito, non só unha certa caracterización dos mariñeiros bretóns cos galegos, senón tamén a súa propia identificación como autora con Dumas, escritor que non dubida en mencionar para deixar claro, por un lado, que é coñecedora das novelas do francés e, por outro, que partilla unha visión desde o centro á periferia (Madrid / Galicia) semellante á de Dumas (París / Bretaña).

Outra cita interesante atopámola no capítulo XX de La hija del mar, que comeza cos versos dun poema de Victor Hugo: «Et que ton âme, errante au milieu de ces âmes / y soit la plus abjecte entre les plus infames! $\gg^{7}$ (Castro 2005: 299). Esta cita do capítulo XX, titulado «Justicia de Dios» provén dun poema titulado "A l'homme qui a livré une famme", onde maldí a sorte do home que, dunha forma ou doutra, traizoa unha muller. Victor Hugo compara este home cun xudeu (figura moi odiada na época debido ao antisemitismo e a imperante relixión católica), un miserábel a quen lle desexa toda casta de penalidades en vida até que a morte leve a súa alma para o inferno, onde chegue a ser a peor alma entre as que alí están. Rosalía aproveita estes versos, non exentos dunha forte carga en defensa da honra feminina (sabemos que Victor Hugo tamén fixo moito polos dereitos das mulleres) para encadralos no final da súa novela onde Ansot se desenmascara para o lector como pirata e malfeitor, é

\footnotetext{
7 «E que a túa alma, errante no medio desta almas / sexa a máis abxecta entre as máis infames.» Tradución propia.

8 «Ao home que traizoou unha muller», tradución propia.
} 
aquí, onde a cita de Victor Hugo cobra sentido para o lector, pois é cando este comprende que Ansot é, en definitiva, un asasino que burlou dúas mulleres. A novela remata cunha mostra de fraternidade entre nai e filla, ambas vítimas das falcatruadas de Ansot, mentres Teresa abraza e bica o cadáver de Esperanza, antes de ser de novo engulido polo mar.

$\mathrm{Na}$ obra de Rosalía a relación entre fillos e proxenitores, especialmente a relación nai e filla ten un valor simbólico importante. Xa desde as súas primeiras obras (La hija del mar, como acabamos de ver, aborda de cheo este tópico) Rosalía non dubida en escribir sobre este asunto, xa sexa en prosa, como vimos, ou en verso, en poemarios como A mi madre (1863). Sen entrarmos en cuestións biográficas, poderiamos aquí dar explicación a este fenómeno aludindo ao presunto mito do abandono da pequena Rosalía por parte da súa nai, mais parece ser que, como xa se tratou no seu momento, as últimas investigacións sobre esta cuestión desmenten esta idea do abandono materno, do que non dubidamos é da importancia deste tema no imaxinario rosaliano:

¡Infelices expósitos! Infelices los que, abandonados a la caridad pública desde el momento en que vienen a la vida, vagan después por la tierra sin abrigo y sin nombre; pobres desheredados de las caricias maternales y de todo cuanto puede dar felicidad al hombre en este valle de dolor. ¡Infelices!... de ellos es el pan de las lágrimas y de ellos la soledad y el abandono. (Castro 2005: 193)

Dun xeito ou outro, Rosalía parece estar moi atenta durante toda a súa vida ás historias de fillos ilexítimos (Ruiz 1986: 369), como se pode ver noutra cita que alude á autora francesa Delphine de Girardin (Delphine Gay de solteira): «Mais dont le solennel délire / annonceà tous que le dieu va parler!...»". É coñecida por seguir os pasos de Madame de Staël, tamén citada por Rosalía no prólogo de La hija del mar e por ser a esposa de Émile de Girardin, fillo, como Rosalía dunha relación extramatrimonial, quen foi un destacado xornalista e escritor de obras nas que defende o dereito dos nenos fillos de relacións socialmente non aceptadas a seren dignos da educación e a aceptación social que se lles negara até o momento (Ruiz 1986: 369).

George Sand é, sen dúbida, unha das autoras francesas máis citadas en textos de Rosalía, con todo, nas citas referidas a autora francesa aparece citada polo seu pseudónimo masculino, Jorge Sand, por exemplo, nos capítulos III, VIII e XVIII, que a xuízo do profesor Ruiz Silva, pertencen á novela Francisco, el expósito (1848) na que Sand se interesa pola historia dun rapaz de incertas orixes (1986: 369). Nunha carta ao seu marido, Manuel Murguía, Rosalía dá conta dunha lectura que fixo da autora francesa: "Las damas verdes ${ }^{10}$ de Jorge Sand tiene muchísima semejanza en ciento estilo con mi joven azul. ¿Qué te parece? Van a decir que he querido imitarla" (Castro 1993 II: 602). Este fragmento danos moita información sobre o panorama literario español da época. Descoñécese de que ano exacto é esta carta, de todos os xeitos, As damas ver-

\footnotetext{
9 «Mais o solemnre deliro / anuncia a todos que o deus vai falar!...» Tradución propia.

10 A cursiva é miña, non está marcado como o título dunha obra no orixinal.
} 
des (traducida para o galego en xaneiro de 2017) apareceu por primeira vez en Francia no ano 1857, xusto unha década antes da publicación de El caballero de las botas azules, novela á que Rosalía se refire cando escribe «mi joven $a z u l »$. Este fragmento indícanos tamén, que a autora francesa sería bastante coñecida no mundo literario español, doutro xeito, Rosalía non estaría preocupada polas posibles acusacións de imitación.

Con todo, é no prólogo de La hija del mar onde Rosalía louva a fermosura do escrito por Sand, «ise escribieron acaso obras más bellas y profundas al frente de las obras de Rouseau que las de la autora de Lélia!» (Castro 2005: 78). Neste prólogo, ademais, a autora de Padrón non dá só conta dos seus amplos coñecementos de literatura francesa, senón tamén de obras de filosofía ou política escritas por mulleres:

Posible me sería añadir que mujeres como madame Roland, cuyo genio fomentó y dirigió la Revolución francesa en sus días de gloria; madame Staël, tan gran política como filósofa y poeta; Rosa Bonheur, la pintora de paisajes sin rival hasta ahora; Jorge Sand, la novelista profunda, la que está llamada a compartir la gloria de Balzac y Walter Scott; Santa Teresa de Jesús, ese espíritu ardiente cuya mirada penetró en los más intrincados laberintos de la teología mística; Safo, Catalina de Rusia, Juana de Arco, María Teresa, y tantas otras, cuyos nombres la historia, no mucho más imparcial que los hombres, registra en sus páginas, protestaron eternamente contra la vulgar idea de que la mujer sólo sirve para las labores domésticas [...] (Castro 2005: 77)

Neste prólogo, que abofé resulta ser todo un manifesto, Rosalía non só reivindica o papel da muller no oficio das letras, enumerando moi válidos e celebrados exemplos de autoras, senón que tamén, practicamente se declara herdeira, primeiro, dunhas madriñas literarias, ás cales enumera e louva no prólogo, e que tamén tamén a acaban definindo como unha autora con moito interese polo que se está a facer en Europa. Proba disto último é que a maior parte das citas que Rosalía trae ás súas obras pertencen a autoras e autores contemporáneos seus. Hai tamén, outras referencias a autores máis antigos (Xoana de Arco, Safo, Catalina de Rusia, Teresa de Ávila), mais polo xeral, case a maioría do que le vido de Francia (Madame de Staël, George Sand, Rosa Bonheur, Balzac, Victor Hugo...) son os seus contemporáneos, o que evidencia en Rosalía unha sede inmensa por saber que se estaba facendo no resto do mundo. Se reparamos neste fragmento desde outra óptica, veremos que case tan importante como presenza das autoras citadas, é a ausencia das autoras que non cita, e se supón que debería citar. Neste fragmento, curiosamente, non están citadas nin Avellaneda nin Böhl de Faber. No último capítulo deste traballo esgrimiremos algunhas hipóteses que dean resposta a esta cuestión.

\section{5.- A tradición alemá}

Canto aos autores da tradición xermánica, podemos dicir que, no xeral, a literatura alemá foi unha grande influencia para Rosalía. Debemos comezar esta 
parte mencionando «Lieders», que aparece en 1958 e sería o primeiro artigo xornalístico que coñecemos de Rosalía. Nótase neste escrito o gusto da autora por este tipo de composicións alemás escritas para ser cantadas, Lied significa canción en alemán ${ }^{11}$, o que xa evidenciaba unha carreira literaria en Rosalía de gran importancia para a musicalidade da súa poesía. Unha das respostas que coñecemos a este artigo escribiuna Benito Vicetto, o chamado Walter Scott de Galicia, nunha carta destinada a Murguía: «Qué diablos le haces a Lieders que no canta?» (Davies 1987: 121), preguntaba Vicetto. Parece que Rosalía xa tiña gañado ese alcume polo seu gusto por esta moda lírica xermánica, que posibelmente chegou á Península antes da aparición da primeira tradución ao castelán do famoso libro Buch der Lieder (1827) de Heinrich Heine, traducido como El libro de los cantares, a cal non foi posible até ben entrada a segunda metade do século XIX. Podemos especular aquí coa posibilidade de que Rosalía puidese ter acceso a algunha tradución francesa da obra de Heine, antes das primeiras publicación das traducións de algúns poemas soltos en diversos xornais do país.

Se seguirmos a tirar do fío da tradición xermánica en Rosalía, atoparemos de contado, outra vez en La hija del mar, unha referencia no capítulo II ao ideal de beleza do Romanticismo. Trátase aquí da descrición da casoupa en que moraba Teresa:

La choza de Teresa se hallaba situada en medio de una pequeña llanura rodeada de inmensos y descarnados peñascales, y cercana al célebre santuario de Nuestra Señora de la Barca.

Lugar éste el más apartado y salvaje de aquella comarca, tiene cierta ruda belleza, digna de ser descrita por Hoffmann, y que tal vez sólo puede ser grata a los caracteres tétricos o a las imaginaciones exaltadas. (Castro 2005: 102)

Reparemos en que a beleza da choza percibida pola narradora está asociada a adxectivos como «apartado», «salvaje» e inclusive «ruda belleza», o que a narradora atopa digno de ser descrito por Hoffmann nunha das súas novelas. E. T. A. Hoffmann, autor do movemento denominado Schwarze Romantik ou Romanticismo negro, conxuga nas súas novelas unha mestura do sobrenatural con conto popular, relixiosidade e a beleza do tétrico que posibelmente cativaron a Rosalía. Repárese en que no fragmento citado, temos tamén a conxunción destas características da estética dos contos de terror de Hoffman: un lugar a priori distópico («inmensos y descarnados peñascales») en conxunción co espiritual («cercana al santuario de Nuestra Señora de la Barca», actualmente un santuario cristián, aínda que asentado sobre un lugar de ritos pagáns, fronte á Costa da Morte, no extremo máis occidental da Península), e o máis importante, a apreciación por parte da narradora, como o faría Hoffmann, da beleza nos lugares agrestes, tétricos, bravíos e rudos tan común nos textos románticos.

11 En alemán ein Lied sería, en principio, unha canción musical, aínda que tamén é un tipo de composición lírica feita para ser cantada. Os Lieder de Heine, por tanto, serían poemas pensados para seren cantados, do mesmo xeito que as cantigas medievais. 
Alén destes autores que acabamos de nomear, Rosalía presta especial atención ao que quizá sexa o autor máis celebrado das letras xermanas modernas. O mozo Goethe foi o autor da famosa novela epistolar Die Leiden des jungen Werthers (1774), traducida recentemente para galego baixo o título As mágoas do mozo Werther, novela que Rosalía, supomos, leu en versión francesa, posibelmente con certo retraso, mais case con certeza moito antes do que calquera outro autor da Península. A publicación desta obra de Goethe foi dun enorme éxito e converteuse en todo un best-seller da época, especialmente entre a xuventude. A novela eleva a categoría literaria a pena de amor e aborda de cheo a idea do suicidio.

Esta novela, aínda que pertencente ao movemento alemán Sturm und Drang, é unha das pedras angulares do Romanticismo europeo porque nela conxúganse varias tradicións literarias que, como veremos, Rosalía recollerá tamén na súa obra. O Werther é unha novela sobre a imposibilidade do amor entre dous namorados pertencentes a diferentes estratos sociais que acaba de forma tráxica co suicidio do protagonista. Na novela, Werther é un mozo interesado pola literatura, igual que o é Goethe, o que evidencia un certo carácter autobiográfico, interesado na tradución dos poemas dun bardo da tradición oral escocesa e irlandesa chamado Ossian. Nun episodio da novela, Werther recítalle á súa amada Charlotte os versos deste bardo escocés traducidos por el mesmo. Os dous amantes deléitanse no gozo que lles aportan estas composicións. O que fai Goethe nesta novela é verter esta tradición oral escocesa e irlandesa arredor do bardo Ossian no centro do movemento romántico converténdoo nun referente da imagoloxía mítica do Romanticismo europeo. Goethe, posibelmente sen o saber, estaba a resituar unha tradición case extinta da periferia europea e a revitalizala ao referila por escrito no Werther. Rosalía (e tamén Murguía, posto que compartían biblioteca) saben da existencia e da importancia destas xestas míticas da literatura dos pobos do norte, fortemente emparentadas coa mitoloxía celta. Proba disto é a cita coan que Rosalía dá comezo ao capítulo II:

Voici Minona qui marche dans / sa beauté, le regard baissé et les / yeux pleins de larmes. Ses cheveux / épars flottent au vent inquiet qui / souffle de la colline. ${ }^{12}$ Ossian (Castro 2005: 9)

Rosalía, pola razón que for, atribúelle a Ossian a composición destes versos, aínda que hoxe sabemos, grazas ás investigacións de Ruiz Silva (1986: 370) que tanto esta cita, como outra con que se dá comezo ao capítulo XIII pertencen ao Werther, que Rosalía le en francés. Revisemos isto último: Goethe rescata a tradición oral irlandesa e escocesa de Ossian integrándoa no corazón do movemento Romántico. A través da tradución francesa do Werther, Rosalía le Goethe e cita o heroe mítico na súa primeira novela. O percorrido do mítico bardo non remata aquí. Manuel Murguía, un dos integrantes do famoso faladoiro rexionalista da Cova Céltica, unha libraría da Coruña onde se xuntaban de forma habitual a partires da década dos setenta do sécullo XIX varios intelec-

12 «Velaquí Minona que camiña coa súa beleza, ca mirada baixa e os ollos cheos de bágoas. O seu cabelo revolto flota ao vento inquedo que sopra desde o outeiro», tradución propia. 
tuais, entre eles Eduardo Pondal, Galo Salina, Lugrís Freire ou Xosé Baldomir, tamén dará boa conta deste mito do bardo escocés. A idea de Murguía de que as orixes da cultura galega se atopa nos celtas foi moi ben recibida entre os tertulianos da Cova Céltica, especialmente por Eduardo Pondal, quen asumirá máis tarde o papel de bardo dos galegos. Foi a través de Rosalía e as súas lecturas (xunto co seu marido) como se trouxo para Galicia a idea do bardismo? Tal afirmación precisa dunha investigación máis rigorosa e detallada cás liñas hipotéticas que acabamos de trazar. Gustaríanos chamar a atención sobre a conveniencia dunha investigación que ilumine o percorrido do bardismo en Galicia, idealmente á luz das lectura do matrimonio Murguía-Castro.

Unha última cita de Goethe pódese atopar, como xa mencionamos, no capítulo XIV de La hija del mar que leva por título "El entierro" onde Rosalía toma prestadas as palabras últimas do Werther: «Des ouvriers portèrent le corps. Aucun prête ne l'accompagna ${ }^{13}$ (Castro 2005: 233). A pertinencia desta cita neste capítulo explícase pola reticencia da Igrexa a dar enterramento cristián ás persoas que decidían acabar coas súas vidas. Neste capítulo, Fausto é enterrado após unha noite na que, no seu leito de morte e sumido no delirio, escapa e perde a vida no mar. A morte en pecado de Fausto non permite que o seu corpo sexa enterrado en terreo sagrado. Pensábase que o cadáver de Fausto, sospeitoso se estar endemoñado, podería infectar co ar de morto aos demais veciños. A superstición xoga un papel moi importante na novela, pois os veciños chegan a propoñer botar o seu corpo ao mar, o cal non debía devolvelo nunca. No Werther de Goethe o protagonista tampouco é digno dun funeral cristián por ser un home que acabou coa súa propia vida por causa do desamor, do mesmo xeito que o Fausto e a Esperanza de La hija del mar, Werther e Charlotte solucionan de forma fatídica a imposibilidade do seu amor.

Existen na obra de Rosalía tamén referencias a outras obras de Goethe. No Fausto, ou polo menos a súa primeira parte, aparece unha alusión ao ritual que hai que facer para convocar ao demo se se quere facer con el un pacto, como fai Fausto con Mefistófeles na obra de Goethe. Rosalía escribe: «El silencio y la soledad de la noche podían favorecer sus conjuros y sus misterios, y la tierra desierta prestaba ancho campo para sus círculos mágicos, pero ellos seguían en su incesante carrera interminable y sin fin.» (Castro 2005: 223). O procedemento para convocar o demo, tal e como se describe na primeira parte do Fausto de Goethe, consiste, curiosamente, en debuxar un círculo arredor de si mentres se pronuncian unhas palabras. Este mesmo círculo, xeralmente feito con sal, pode servir para protexerse das forzas do mal, segundo a tradición. Esta figura serve, por un lado, para convocar e, por outro, para protexerse do que se convoca. Nesta mesma liña, atopamos composicións da época co mesmo motivo do círculo debuxado no chan a modo de protección contra os malos espíritos:

Comecei á rezar / pasin un padre-nuestro: e naquel punto / fijen un circo c'o meu pau d'oliva, / que ja bendito (por si acaso) iba, / e posto dentro d'el: -Eu te requero / de parte de... -lle dijen tremelando. (López de Serantes 1986: 168)

13 «Os obreiros levaron o corpo. Ningún cura o acompañou», tradución propia. 
Este poema pertence ao poeta Francisco Añón, contemporáneo de Rosalía e veciño de Outes, non moi lonxe de Padrón, a vila na que se asentou a familia Murguía-Castro varios anos antes da morte de Rosalía. O poeta Añón recolle nestes versos tamén o procedemento polo cal, supostamente, un pode invocar ó demo. A de Rosalía e a do poeta Añón son dúas mostras moi próximas, tanto no tempo coma no espazo xeográfico, do presente que estaban no imaxinario popular este tipo de ritos. Isto evidencia tamén que os valores estéticos do Romanticismo, ben como os seus temas, permiten que se eleven á categoría literaria e se escriban e circulen como literatura certas crenzas ou motivos asociados á cultura popular. Non se trata aquí de establecer que tanto o poeta Añón como Rosalía foron ávidos lectores de Goethe, pois non temos as probas necesarias para afirmar tal cousa. Recordemos que a correlación (o feito de que dous autores traten un mesmo tema) non envolve causalidade. Con todo, o feito de atoparmos este motivo en tres autores diferentes, si sería un bo indicativo, como nos di Arturo Leyte (2014: 563-564) de que «más allá de las influencias, y antes de ellas, Rosalía es importante porque escucha por sí misma el inconsciente de su tiempo».

Esta capacidade para escoitar o inconsciente da súa época levará a Rosalía, como nos explica Leyte, a partillar voz poética con autores, como Hölderlin, en aspectos como «la limitación del conocimiento humano, incapaz de captar una realidad inapresable e incompleta» (Leyte 2014: 563). Estas interpretacións da obra de Rosalía, especialmente da súa poesía en termos de incapacidade, sexa para a comprensión do mundo, ou para expresalo a través da palabra, verten moita luz sobre o pensamento rosaliano e están en completa consonancia co pensamento de outros autores da súa época. Volvendo a Hölderlin, nun dos poemas que Heidegger utiliza para abordar de forma fenomenolóxica a experiencia do recoñecemento, vemos como o poeta romántico fai unha distinción entre as diferentes formas coas que un pode calar: «A menudo debemos callar; pues faltan nombres sagrados. / Laten los corazones y, no obstante, ¿se queda atrás la palabra?» (Heidegger 2005: 15). Compárese a idea destes dous versos con estoutros do poema que pon fin a "Vaguedás", o primeiro capítulo de Follas Novas:

¡Silencio! / A man nerviosa e palpitante o seo, / as niebras nos meus ollos condensadas, / con un mundo de dudas nos sentidos / i un mundo de tormentos nas entrañas, / sentindo cómo loitan / en sin igual batalla / inmortales deseios que atormentan / e rencores que matan, / mollo na propia sangre a dura pruma / rompendo a vena hinchada, / i escribo..., escribo..., ¿para qué? ¡Volvede / ó máis fondo da ialma, / tempestosas imaxes! / ¡Ide a morar cas mortas relembranzas! / ¡Que a man tembrosa no papel só escriba / palabras, e palabras, e palabras! / Da idea a forma inmaculada e pura / ¿dónde quedóu velada? (Castro 1993 II: 286)

Este poema coparte co de Hölderlin a expresión da imposibilidade de escribir o que se sente, mais tamén, se callar, da inutilidade do escrito para soster o sentido, resultando en só «palabras, palabras e palabras». Segundo Hölderlin, tórnase imposíbel nomear, pois «faltan os nomes sagrados». Os poetas reparan 
na dificultade de expresar coa pluma "a forma inmaculada e pura da idea" e perante esta encrucillada, os dous poetas debátense entre gardar silencio ou escribir con sangue.

\section{4.- As influencias inglesas e estadounidenses}

Se reparamos de novo no antepenúltimo verso deste poema de Follas Novas que vimos de tratar, atoparemos de novo unha referencia que nos leva ó primeiro autor inglés que influencia a Rosalía. O autor do Hamlet pon en boca do príncipe de Dinamarca no segundo acto da traxedia a famosa cita que Rosalía recolle neste poema: «palabras, palabras, palabras». Esta non é a única traxedia de Shakespeare que Rosalía cita. Macbeth tamén aparece ao final do capítulo IX de La hija del mar:

Y fue tal la exaltación de sus celos que pensó en el crimen; nube negra que pasó ante sus ojos como un relámpago y rehusó manchar sus manos en sangre inocente que, como la de Macbeth, teñiría los mares; rehusó al crimen, y tuvo que resignarse a su suerte, aunque sabía muy bien que ella sucumbiría en la lucha. (Castro 2005: 192)

Esta referencia ao personaxe da obra de Shakespeare explícase pola idea de vinganza que pasa pola cabeza de Esperanza. A imaxe do sangue que tingue o mar é, como na obra do poeta inglés, un símbolo dos remorsos polo crime cometido, que nesta ocasión, na novela de Rosalía, non chega a perpetrarse. Os ciúmes son tantos e a aldraxe é de tal magnitude que a protagonista chega a contemplar a vinganza, con todo, para Rosalía a dúbida e a cuestión ten máis importancia literaria que a certeza e só pode ser comparada á forza do destino, un dos motores pirincipais que moven as tramas románticas. Xa que logo, Esperanza abandona a idea do crime e «resígnase á súa sorte».

Hai, ademais desta, outra referencia á obra de Shakespeare. Durante o episodio en que se conta a morte e aventuras do cadáver de Fausto (capítulo XIV), nárrase unha escena en que o corpo do finado é velado. A narradora deixa entrever as similitudes dos que alí rezan coa imaxe da Santa Compaña:

Semejaban en aquel momento conjuro de endemoniados, reunión de diabólicos seres prontos a sacrificar la víctima arrastrada hasta allí por sus ásperas manos, y sometida ya al poderoso influjo del infierno.

Aquellas luces oscilantes, aquellos rostros atezados y sombríos, aquel rezo ronco y triste, $\mathrm{y}$ aquel silencio sepulcral que reinaba en torno, formaban un siniestro conjunto que hubiera amedrentado al espíritu más fuerte.

¿Qué hacían semejantes hombres?

Ellos podían responder a esta pregunta lo que las brujas de Macbeth...

-¡Una cosa sin nombre! -y habrán dicho la verdad. (Castro 2005: 242) 
Isto remítenos á primeira escena do cuarto acto da traxedia de Shakespeare onde Macbeth pregunta ás meigas: « ¿Y ahora qué, secretas y oscuras brujas de la noche? ¿Qué estáis haciendo?»E como o lector xa suporá, as meigas responden ao unísono: «Una cosa sin nombre» (Conejero 1998: 229).

Non debería xa sorprender que entre os autores ingleses que influenciaron a Rosalía estean Walter Scott ou Lord Byron, ambos xa mencionados en capítulos anteriores por causa da asiduidade con que aparecen, dun xeito ou doutro, entre as liñas da obra de Rosalía. Canto ao heroe romántico inglés por excelencia, diremos que a súa obra Manfredo (1817), con grandes influencias da primeira parte do Fausto de Goethe, aparece citada unhas cinco veces en La hija del mar. Esta obra de Byron sitúase nos Alpes suízos, onde o inglés recrea un escenario cheo de seres como fadas, meigas e demos. Rosalía é consciente do potencial que ten a costa galega de Fisterra para inspirar escenarios románticos, tanto pola orografía en si, como pola cantidade de lendas sobre o paranormal. Reparemos no seguinte fragmento, onde a autora describe a singularidade da súa terra, facéndoa digna de aparecer nunha novela de Byron:

Si Byron, ese gran poeta, el primero sin duda alguna de este siglo, hubiese posado sobre el desnudo cabo de Finisterre su mirada penetrante y audaz, hubiéramos tenido hoy tal vez un cuadro más en su Manfredo, o algunas de aquellas grandiosas creaciones inspiradas bajo el sereno cielo de la Grecia, y con la cual haría ver al mundo que hay en este olvidado rincón de Europa paisajes dignos de ser descritos por aquel que era el más grande de los poetas.

Aquel paisaje, uno de los más desolados y tristes que pueden hallarse en Galicia y quizás aun en la mayor parte de España, armonizaba admirablemente con el carácter de la expósita, acostumbrada a la soledad y a la vida errante. (Castro 2005: 102-103)

Neste fragmento, a autora no só eloxia a paisaxe galega, describíndoa como merecedora de ser descrita por Lord Byron no seu Manfredo, senón que tamén articula unhas das características principais do movemento romántico: a correlación entre un elemento paisaxístico e o estado de ánimo ou personalidade dun personaxe, como ben se pode ver nas últimas liñas do fragmento referido.

No que se refire a Walter Scott, atópase no capítulo XVIII de La hija del mar unha referencia que, segundo Ruiz Silva, ten un parecido razoábel co final da ópera Lucía de Lammermoor, baseada na obra The Bride of Lammermoor do novelista escocés:

-Cuando ella haya muerto -decía Ansot-, si me quedan aún fuerzas y valor, ya hallaré modo de librarme del horrible peso de mi desgracia. ¿Qué es la vida en el aislamiento cuando el alma se acerca sedienta a un raudal que acaba de secarse a su vista? ¡Carga pesada e inútil!... (Castro 2005: 283)

Este lamento que Rosalía pon en boca de Alberto ten, como refire Ruiz Silva (1986: 357), un certo parecido con esta ópera inspirada na novela de Scott: «Per me la vita è orrendo peso!...» A esta obra, Rosalía puido ter acceso na 
súa representación en Madrid no Teatro Real durante a súa estadía na capital, algo que non nos debe estrañar se temos en conta o gusto da poeta polo teatro e a música.

O mesmo Ruiz Silva dános a indicación de outra autora inglesa á que Rosalía puido ter lido. Charlotte Turner Smith (1749-1806), poeta e novelista inglesa, gabada por autores de renome como Charles Dickens e Jane Austen, escribe en 1788 a novela Emmeline, na que se conta a historia dunha muller (curiosamente outra vez a historia dunha orfa, como así refine no título orixinal Emmeline, the orphan of the castle) que rompe coas normas socioeconómicas, vira rica e critica os matrimonios concertados, tan correntes naquela época.

Outra autora, desta volta, do outro lado do océano Atlántico, é citada ao menos en dúas ocasións en La hija del mar. Maria Susanna Cummins ${ }^{14}$ é a autora de The Lamplighter, unha novela romántica de aprendizaxe (Bildungsroman, o termo orixinal en alemán) publicada nos Estados Unidos en 1854, con tanto éxito que no mesmo ano se publicou a tradución ao francés. The Lamplighter é un dos máximos expoñentes da literatura gótica estadounidense con notorias semellanzas con La hija del mar, concibida en recentes investigacións filolóxicas como unha das poucas mostras da novela gótica española. Debemos agradecerlle aquí a autora de Padrón o ter creado na costa galega un espazo orixinal de ambientación para este tipo de novela. Como o profesor Domínguez (2014: 514) explica, esta cuestión pode verse con facilidade se observamos os fluxos de tradución do xénero gótico europeo:

Neste mesmo sentido, quizais poida considerarse que o limitado uso de España como espazo de ambientación do gótico por parte dos escritores ingleses se debe ao papel menor no cultivo do gótico polos escritores españois dentro do panorama europeo, que é facilmente mensurábel en función dos fluxos de tradución, cunha balanza totalmente desequilibrada cara á importación de textos ingleses e franceses, cun papel mediador reservado en exclusiva a Francia e cun interese dominante polo «gótico feminino».

Isto explica a cantidade de novelas góticas, especialmente escritas por mulleres que Rosalía cita en La hija del mar. A fin de contas, esta inxente cantidade de citas pode ser considerada unha tentativa de tomar posición nun movemento literario europeo (a novela gótica) do que Rosalía estaba moi interesada en formar parte. Outra vez, en palabras do profesor Domínguez (2014: 517), toda esta información acerca da xenealoxía e as influencias de Rosalía, son datos dunha "mostra significativa dese «mar literario» en que Rosalía de Castro mergulla, alimentado como nunca antes por escritoras".

14 Rosalía refírese á autora como "Miss Cummings" nunha cita en francés que dá comezo ao capítulo IX e tamén ao XV, este erro no nome da estadounidense pode que se deba á recepción por parte de Rosalía dunha tradución na que non se respectou o nome orixinal, ou a tamén, máis probablemente a un erro de transcrición da propia Rosalía. A novela de Susanna Cummins tradúcese ao francés en 1855, ano no que aparecen as traducións Émile da Bédollière e Frédéric-Germain de Lagny (Domínguez 2014: 517). 
Un último autor que debemos por en relación con Rosalía, en referencia tamén á literatura gótica, é o estadounidense Edgar Allan Poe. Rosalía menciona nunha carta a Murguía que ela estivo a ler un conto de Poe: «He leído ayer un cuento de Poe, precioso aunque sencillo. Allí comprenderás que era poeta. Otro que he leído de él, de un género opuesto, se parece al modo de escribir de Larra» (Castro 1993 II: 602).

\section{6.- Outras influencias}

Deixamos para este apartado final aqueles autores que, por unha ou outra razón nos foi imposíbel tratar en capítulos anteriores. Chámanos a atención, decontado, a relación que pode haber entre Rosalía e as letras portuguesas. A última obra de poemas do Visconde de Almeida Garret foi publicada en 1853 baixo o título Folhas caídas. Tanto polo xénero, a proximidade xeográfica, como polo seu suxerente título, sería preciso investigar a relación que hai entre as Folhas caídas de Almeida Garret e as Follas Novas de Rosalía, como así apunta o matrimonio Pociña-López (1991: 621).

Outra liña que nos desperta ineterese é aquela do autor citano no inicio do primeiro capítulo de La hija del mar: «Era amable y graciosa como un ángel» (Castro 2005: 81). Resúltanos bastante difícil de identificar quen é o Van der Welde que asina a cita. Pode que o nome non estea ben escrito e se refira ao escritor alemán Carl Franz van der Velde (1779-1824) tamén coñecido como o "Walter Scott alemán" por escribir novela histórica coma o escocés, mais é preciso facer máis investigacións sobre o asunto.

Damos por finalizado aquí este capítulo no que nos ocupamos, nun primeiro momento, de identificar os autores e autoras referenciados (xa for de forma explícita ou non) en textos de Rosalía. A través deste exercicio de literatura comparada, pretendemos, por un lado, reforzar a idea dunha Rosalía lectora e atenta ao panorama literario europeo e mundial da súa época, ben como a súa capacidade para ouvir a "voz do seu tempo". Por outro lado, recoñecer e evidenciar o importante papel que tivo na configuración dos fluxos literarios da súa época, tanto aqueles que teñen como dirección as grandes literaturas do Romanticismo para as máis periféricas, como o seu papel na configuración dunha novela gótica na literatura española, como o inmenso esforzo de revitalización e prestixio da lingua galega como lingua literaria.

\section{II.- A FRONTEIRA IDENTITARIA. QUEN FOI ROSALÍA?}

Se o anterior capítulo visaba situar a obra de Rosalía de Castro no conxunto do panorama da literatura española e europea a través das relacións que establece cos seus contemporáneos, o presente capítulo pretende definir o perfil autoral de Rosalía lonxe das clasificacións, en gran medida, binarias e reducionis- 
tas ${ }^{15}$ posiblemente saídas da tradición estruturalista nos estudos sociais, que se lle impuxeron tanto na historiografía literaria galega como na castelá.

Lonxe de encadrar aquí o debate filosófico sobre a validez das ideas estruturalistas aplicadas ós estudos literarios, si nos interesa para o último capítulo deste ensaio formular unha serie de oposicións a modo de paradigmas para ver que, en case todos os casos, Rosalía toma unha posición fronteiriza entre ambos, o que fixo tan complicado historiograficamente encadrala por completo e de forma satisfactoria en calquera categoría. Os paradigmas que imos tratar asócianse dun xeito ou doutro cos conceptos de centro e periferia, desta volta xa non entendidos de forma territorial, ou vencellados aos polisistemas literarios, senón aplicados a outros eidos da figura dun autor. Deste xeito, como veremos, o debate aínda existente entre a prosa e a poesía en Rosalía sería, en definitiva, tamén un debate sobre as relacións centro-periferia, debido a que a prosa ten un papel moito máis central cá poesía no campo literario, mentres que a poesía ocupa un lugar máis periférico. A maioría dos paradigmas que presentaremos neste capítulo poden lerse tamén en torno á dialéctica do centro-periferia.

O primeiro paradigma que debemos contemplar, tratándose Rosalía dunha autora bilingüe, é o do galego / castelán. Existen certas dificultades para aceptar o carácter bilingüe de Rosalía de Castro. Desde a historia de literatura castelá, estúdanse principalmente as súas obras en castelán (especialmente aquelas en verso). Tanto Cantares como Follas novas aparecen como textos anecdóticos ou rexionais. Desde a historia da literatura galega formúlase o contrario: Rosalía como autora constrúese unicamente a través dos dous grandes textos escritos en galego e óbviase a maior parte da súa prosa en castelán. Ben é certo que a importancia para a literatura galega deses dous textos, nomeadamente do primeiro, é inmensa e innegábel, mais é precisa quizá unha historia literaria menos ligada ás linguas e máis receptiva a ser

15 O filósofo belga Claude Levi-Strauss publicou en 1964 unha obra en que aplicaba un enfoque estruturalista ás ciencias sociais, especialmente á antropoloxía, área en que el estaba especializado. Esta obra, titulada $O$ cru e o cocido, esbózase como un grande ensaio no que se analizan os fundamentos das diversas civilizacións que poboan a terra reducindo os seus esquemas culturais en torno a dous conceptos en oposición relativos á forma que teñen de consumir os alimentos: crus ou cocidos. Levi-Strauss observou como as sociedades que non cociñaban os alimentos (enténdase por cociñar, esterilizar e transformar as calidades organolépticas e estruturais a través de procedementos térmicos, por norma aplicando calor con lume) e aquelas que, non coñecían o lume e por ende non cociñaban, tiñan unha concepción diferente da realidade. As sociedades que non cociñaban non tiñan unha palabra (tampouco un concepto) para o cociñado, e por tanto, tampouco tiñan unha palabra para o "cru", xa que é un concepto que se crea a partir do seu oposto. A partir desta observación, Levi-Strauss afirmou que é precisa unha certa abstracción da realidade que nos permita entendela mellor. $\mathrm{O}$ que queremos dicir con esta reflexión acerca desta experiencia de Levi-Strauss é que os paradigmas poden resultar nun método de estudo moi válidos, desde que reparemos en que, como di o proverbio latino, o tertium non datur pode que se aplique sen problemas á lóxica e ás matemáticas, mais escasas veces funciona nas ciencias sociais. Sen irmos máis lonxe, hoxe sabemos que, entre o cocido e o cru, está, por exemplo, o fermentado; que muda a composición química, organoléptica e estrutural dos alimentos mais sen necesidade de aplicar calor. 
construída en base a outros factores literarios, por exemplo, a paisaxe, en tanto que topos literario dunha literatura dada. O bilingüismo literario abre portas e permite unha maior amplitude discursiva, que, de certo, crea reticencias noutros autores monolingües, o que explica en certa medida a confrontación entre ambas historiografías.

No relativo a este primeiro paradigma que acabamos de ver, é preciso mencionar a cuestión da polémica desatada após da publicación do artigo "Costumbres gallegas" o 4 de abril de 1881 no que se dá conta «y no para alabarla ni censurarla» (Castro 1993 II: 608) dunha antiquísima tradición dalgunhas zonas costeiras de Galicia. Este costume consiste en que, ao mariñeiro que chegue á terra despois dunha longa tempada embarcado, se lle deixe pasar a noite cunha muller da familia en sinal de máxima hospitalidade:

Entre algunas gentes tiénese allí por obra caritativa y meritoria el que, si algún marino que permaneció por largo tiempo sin tocar tierra, llega a desembarcar en un paraje donde toda mujer es honrada, la esposa, hija o hermana pertenecientes a la familia, en cuya casa el forastero haya de encontrar albergue, le permite por espacio de una noche ocupar un lugar en su mismo lecho. (Castro 1993 II: 660)

A partir da publicación deste artigo, as críticas, especialmente aquelas de parte do conservadorismo galego, foron numerosas e feroces contra a presunta falta de moralidade da autora. Existe constancia dunha carta enviada de Rosalía a seu marido na que ela se queixa do trato e as respostas recibidas pola publicación deste artigo. Nesta carta é onde se menciona a famosa cuestión da dimisión lingüística:

[...] me extraña que insistas todavía en que escriba un nuevo tomo de versos en dialecto gallego. No siendo porque lo apurado de las circunstancias me obligaran imperiosamente a ello, dado caso que el editor aceptase las condiciones que le dije, ni por tres, ni por seis, ni por nueve mil reales volveré a escribir nada en nuestro dialecto, ni acaso tampoco a ocuparme de nada que a nuestro país concierna. (Castro 1993 II: 608)

Hai quen quere ver este episodio da vida de Rosalía como una especie de dimisión das súas obrigas co proxecto de revitalización cultural que comezou con Cantares. O paradigma dimisión / decisión pon en oposición a actitude da maioría dos investigadores da obra de Rosalía. Hai quen entende que este amargo episodio provocou nela a decisión de non volver escribir en galego e hai quen o entende como unha dimisión, non só autoral, senón máis profunda, cunha magnitude case vital e persoal. O certo é que, cando Rosalía publica Follas novas, un ano antes desta polémica, xa aludía no prólogo a que esas serían probablemente ás últimas páxinas que escribía en galego: «Alá van, pois, as FOLLAS NOVAS, que mellor se dirían vellas porque o son; e últimas, porque pagada xa a deuda en que me parecía estar coa miña terra, difícil é que volva escribir máis versos na lingua materna» (Castro 1993 II: 273). Parece ser, pois, 
que a decisión de non volver escribir en galego estaba xa tomada antes da polémica. Por outro lado, outros investigadores como Francisco Rodríguez entenden que esta decisión de Rosalía non sería definitiva, e en todo caso, froito dunha "comprensíbel" reacción emocional (Rodríguez 2001: 489).

Dun xeito ou doutro, parece que esta é unha cuestión que non se chegará a resolver de todo, pois antes de Rosalía morrer, rogoulle ás súas fillas que queimasen todos os manuscritos que había sen acabar. Porén, nunca saberemos se entre os papeis que se queimaron había outros proxectos de obras en galego.

Canto ás súas obras, existe tamén un desacordo acerca do binomio prosa / poesía. Rosalía cultivou ambos xéneros nos dous idiomas, e non só. A isto hai que engadir os artigos e as crónicas que escribiu para diferentes xornais. Parece haber, non obstante, certa intención en considerar a Rosalía, ante todo, poeta, o cal non é desatinado, mais hai que ter en conta que o xénero que Rosalía máis cultivou foi a prosa. As súas aspiracións e gustos, como indican as lecturas e citas que analizamos no capítulo anterior, dan proba da predilección que Rosalía tiña polas obras en prosa, e ademais, escritas por mulleres. Para ilustrar a relación entre os xéneros e as linguas que se manexan na obra de Rosalía, a seguinte táboa ${ }^{16}$ mostra as publicacións da autora organizadas por linguas e xéneros literarios:

\begin{tabular}{|c|c|c|c|}
\hline & Obras en prosa & Obras en verso & $\begin{array}{l}\text { Artigos, crónicas e } \\
\text { manifestos }\end{array}$ \\
\hline Castelán & $\begin{array}{l}\text { - La hija del mar } \\
\text { - Flavio } \\
\text { - Ruinas } \\
\text { - El caballero de las } \\
\text { botas azules } \\
\text { - El primer loco. } \\
\text { Cuento extraño. } \\
\text { - El domingo de Ramos }\end{array}$ & $\begin{array}{l}\text { - La flor } \\
\text { - A mi madre } \\
\text { - En las orillas del Sar }\end{array}$ & $\begin{array}{l}\text { - "Lieders" } \\
\text { - "Las literatas. Carta } \\
\text { a Eduarda" } \\
\text { - "El cadiceño" } \\
\text { - "Padrón y las } \\
\text { inundaciones" } \\
\text { - "Costumbres } \\
\text { gallegas" }\end{array}$ \\
\hline Galego & $\begin{array}{l}\text { - "Conto gallego" } \\
\text { ("Contos da miña } \\
\text { terra") }\end{array}$ & $\begin{array}{l}\text { - Cantares gallegos } \\
\text { - Follas novas }\end{array}$ & \\
\hline
\end{tabular}

Como vemos, no conxunto da obra rosaliana predomina a prosa en castelán. Trátase ademais, en moitos casos (La hija del mar, El caballero de las botas azules...), de novelas de varios centos de páxinas, con que xa se require, por parte dun autor, unha certa dedicación vital a tal proxecto. Como nas categorías anteriores, resulta imposíbel encadrar nunha soa categoría a Rosalía. O seu lugar é, como vimos dicindo, a fronteira, mais non dun modo estático entre

16 Elaboración propia. 
dous territorios, senón dun xeito dinámico, indo e volvendo do verso á prosa e dun idioma a outro.

Moi en relación coa cuestión do xénero literario está a dicotomía alta cultura / cultura popular. A mediados do século XIX a novela era xa un xénero literario asociado á burguesía e á alta cultura. Rosalía cultivou a novela mais tamén compuxo como compoñen as mulleres do campo. Non esquezamos que a maior parte dos Cantares comeza cunha parte en glosa, é dicir, son poemas inspirados e compostos a partir de composicións populares orais preexistentes. Rosalía pretende, pois, elevar a categoría destas composicións e á vez a da lingua e a do pobo que as deron. A vida persoal de Rosalía remítenos tamén a unha realidade híbrida, hai, na súa mesma persoa, a conxunción de dous estamentos sociais: a nobreza e o campesiñado. Por un lado, a súa nai, fidalga vinda a menos, por outro, seu pai, un sacerdote de familia labrega. Na súa obra tamén se ve unha posición fronteiriza entre estes dous estamentos sociais. Por un lado, se pensamos no lector obxectivos dos Cantares ou de Follas novas, veremos como ambas obras foron escritas pensando nas clases populares galegas. Pola contra, as súas novelas en castelán parecen máis indicadas a satisfacer os gustos estéticos das clases sociais acomodadas castelás.

A adscrición de Rosalía a un gran movemento literario tampouco é tarefa doada. É Rosalía romántica ou realista? O seu lugar, unha vez máis, está no terreo intermedio entre ambos. É preciso dicir que os movementos literarios non aparecen en bloque dun día para outro como se pode facer crer nun libro de texto. Un movemento literario é un conxunto de autores e obras vivos que se interrelacionan entre si. Rosalía escribe nun tempo de mudanza, nun período entre o Romanticismo truncado español e a chegada dos grandes realistas. Novelas como La hija del mar teñen, como xa vimos no anterior capítulo, os atributos todos para ser unha gran mostra da novela gótica europea. Os Cantares rescatan as antigas cantigas de amigo medievais, gardadas e tranmitidas durante séculos nas voz das mulleres do campo. La flor ou En las orillas del Sar brillan cun lirismo íntimo e pegado á natureza, mais tamén están atentos á preocupación polos límites do home, na liña de Hölderlin ou do italiano Leopardi. El primero loco é unha novela estraña, moi difícil de encadrar, mais na que se ve xa o amencer do Modernismo. "Las literatas" é un artigo, un manifesto irónico, no que unha escritora advirte dos perigos e as incomodidades da profesión a outra moza con desexos de coller a pluma. Trátase, ao fin e ao cabo, dun pequeno ensaio sobre a igualdade de xénero nun mundo, o literario, aínda dominado polos homes.

Estas oposicións que acabamos de ver definen a Rosalía como unha autora que mantivo un diálogo ao longo da súa vida e da súa obra entre o centro e a periferia. Non nos referimos aquí exclusivamente a cuestións xeográficas ou xeopolíticas, ou á cuestión da centralidade dos sistemas literarios, senón ao feito de que ser muller escritora a mediados do século XIX significaría pertencer á periferia do sistema literario. Escribir nunha lingua como o galego, era escribir na lingua da periferia da sociedade nun momento crucial para a literatura europea. 


\section{3.- CONCLUSIÓNS}

Existe unha fenda nos estudos rosalianos que divide a crítica da súa obra en castelán e aquela en galego. Esta fenda separa tamén, en parte, os estudos críticos da súa prosa e a súa lírica. Faltan, aínda a día de hoxe, estudos en conxunto da totalidade da súa obra que salven esta fronteira lingüística.

Rosalía é unha dos moitos autores bilingües que se viron afectados pola construción de historiografías literarias nacionais e monolingües. Por un lado, a historia da literatura castelá obvia a importancia das súas obras en galego. A galega obvia a importancia das súa prosa en castelán. Conxugar as dúas é verdadeiramente un desafío que agardamos sexa levado a cabo canto antes.

A obra de Rosalía ten moito para nos dicir. Son precisas novas lecturas da súa obra á luz dos desafíos que trae o presente. Xa se fixeron, por exemplo, lecturas en clave marxista e antisistema dalgunha novela, así como tamén diversas aproximacións feministas á súa obra. Isto é unha boa proba do potencial discursivo que garda aínda a súa obra e que cómpre debullar.

Proba da importancia da obra rosaliana na literatura europea e, porén, na nova configuración política, social e cultural do continente á que asistimos na actualidade, é a súa capacidade para absorber con intelixencia e habilidade o mellor do que se estaba a facer en Europa.

Rosalía establece unha relación de diálogo a través da súa obra entre os diferentes autores da súa época. Propuxemos neste traballo algunhas pistas para a súa descodificación e interpretación. Pola contra, queda aínda moito por facer neste eido.

Consecuentemente, é preciso resaltar aquí a súa importancia, por un lado, na configuración da literatura europea e española. Por outro, o seu xeito para verter no debilitado sistema literario galego da súa época a cerna do que estaba a acontecer no eido literario europeo.

Para rematar, cómpre tamén salientar a importancia da obra de Rosalía de Castro á hora de habilitar novos espazos de acción ao se situar entre extremos opostos. Queremos destacar, por último, o carácter transgresor, subversivo e fronteirizo da súa obra.

\section{BIBLIOGRAFÍA}

Acosta Romero, L. A. (1990): “El barón, comedia neoclásica. Aproximación a su estructura interna". Philologia Hispalensis, IV, I, pp. 417-431.

Castro, R. de (1990): Obra completa 1. La hija del mar, Flavio, El primer loco, Ángel Abuín (ed.), Patronato Rosalía de Castro, A Coruña.

- (1993): Obras completas vol. I e II, Ed. Marina Mayoral, Madrid, Turner.

- (2014): Epistolario, eds. Helena González, María Xesús Lama y María do Cebreiro Rábade, Santiago de Compostela, Consello da Cultura Galega. 
Dispoñoble en liña na ligazón: < http://consellodacultura.gal/epistolarios/ rosalia.php>. (xaneiro 2018)

- (2005): La hija del mar. Montserrat Ribao Pereira (ed.) Madrid, Akal.

Conejero, M. A. et al. (eds) (1998): Macbeth. Cátedra, Madrid.

Davies, C. (1987): Rosalía no seu tempo. Galaxia, Vigo.

Domínguez, C. (2014): «Sin tino y sin pretensiones. La hija del mar e o labirinto gótico» en Álvarez, R. / A. Angueira / M. C. Rábade / D. Vilavedra (coords.) (2014): Rosalía de Castro no século XXI. Unha nova ollada, Santiago de Compostela, Consello da Cultura Galega, 2014. pp. 503-522.

Espronceda, J. de (1984): El estudiante de Salamanca. Ed. J. M. Díez Tabaeda. Plaza \& Janés, Barcelona.

Even-Zohar, I. (1995): «A posición da tradución literaria dentro do polisistema literario» en Viceversa no 2 (1996) pp. 59-65, X. M. Gómez, C. Noia e M. Sola Bravo (eds.) http://www.tau.ac.il/ itamarez/works/papers/trabajos/ posicion-da-traduccion.pdf (xaneiro 2019)

- (1999): «La posición de la literatura traducida en el polisistema literario», en Teoría de los Polisistemas. Montserrat Iglesias Santos (ed.) Bibliotheca Philologica, Serie Lecturas. Arco, Madrid. pp. 223-231.

- (2013): «O “sistema literário"» en Revista Translatio 4, pp. 22-45, Marozo, Luis Fernando \& Yanna Karlla Cunha (eds.) Dispoñíbel en liña baixo a ligazón <http://www.tau.ac.il/ itamarez/works/papers/trabajos/ Portugues/Even-Zohar_2013--O\%20sistema\%20literario.pdf $>$ (xaneiro 2019)

Heidegger, M. (2005): Aclaraciones a la poesía de Hölderlin. Arturo Leyte e Helena Cortés (eds). Alianza Editorial, Madrid.

Hovasse, J.-M. (2001): Victor Hugo. Fayard, París.

Lévi-Strauss, C. (1964) Mitológicas. Volume I: Lo crudo y lo cocido. Fondo de Cultura Económica.

Leyte, A. (2014): «Rosalía: la voz inconsciente de su tiempo» en Actas do Congreso Internacional de Estudos sobre Rosalía de Castro e o seu tempo, I, Consello da Cultura Galega-Universidade de Santiago de Compostela, Santiago de Compostela.

López de Serantes, X. (1986): Vida e morte dun poeta. Biografía de Francisco Añón Paz. Venus Artes Gráficas, Vigo.

López, A + Pociña, A. (1991): Rosalía de Castro: documentación biográfica y bibliografía crítica (1837-1990). Fundación Pedro Barrié de la Maza, Conde de Fenosa, A Coruña.

Mayoral, M. (1986): «La voz del narrador desde La hija del mar a El primer loco» en Actas do Congreso Internacional de Estudos sobre Rosalía de 
Castro e o seu tempo, I, Consello da Cultura Galega-Universidade de Santiago de Compostela, Santiago de Compostela.

- (1990): «Prólogo» a Follas Novas. Xerais, Vigo.

Rodríguez, F. (2001): Rosalía de Castro, estranxeira na súa patria. Asociación Socio-Pedagóxica Galega, Santiago de Compostela.

Ruiz Silva, C (1986): «Reflexiones sobre La hija del mar» en Actas do Congreso Internacional de Estudos sobre Rosalía de Castro e o seu tempo, I, Consello da Cultura Galega-Universidade de Santiago de Compostela, Santiago de Compostela.

Zorrilla, J. (2003): Don Juan Tenorio. Ed. Montserrat Ribao Pereira, Akal, Madrid. 



\title{
A transposición do infinitivo flexionado ao castelán na tradución de Carmen Martín Gaite d'O Mistério da Estrada de Sintra
}

\section{The Transposition of the Flexed Infinitive to the Castilian in the Translation of O Mistério da Estrada de Sintra due to Carmen Martín Gaite}

\author{
Alberto Gómez Bautista
}

agbtrad@gmail.com

Recibido: octubre 2018. Aceptado: febrero 2019

\begin{abstract}
Resumo: O obxectivo principal deste traballo é analizar os recursos lingüísticos que se utilizan en castelán para traducir o infinitivo flexionado do portugués, forma que non se atopa no paradigma verbal castelán, nunha tradución d'O Mistério da Estrada de Sintra. Ese estudo das formas equivalentes ao infinitivo flexionado empregadas na tradución da devandita obra irá precedido dunha introdución ao estado da arte deste paradigma verbal, unha breve análise da obra orixinal e da tradución castelá máis divulgada, a de Carmen Martín Gaite, que serviu de base para este estudo.
\end{abstract}

Palabras clave: infinitivo flexionado, tradución, portugués, español.

\begin{abstract}
The main goal of this paper is to analyse the linguistic resources used in the Spanish translation, by Carmen Martín Gaite, of $O$ Mistério da Estrada de Sintra written by José Maria Eça de Queiroz and José Duarte Ramalho Ortigão, to translate the Portuguese inflexed infinitive, a form that does not exist in the verbal paradigm of Spanish. The study will also consider the state of the art of this verbal paradigm, as well as an analysis of the original work and its most known Spanish translation, which is the base of this paper.
\end{abstract}

Key words: inflected infinitive, translation, Portuguese, Spanish 


\section{I.- INTRODUCCIÓN}

Neste traballo ${ }^{1}$ analizamos os recursos utilizados para traducir o infinitivo flexionado do portugués ao castelán na tradución que Carmen Martín Gaite elaborou da obra O Misterio da Estrada de Sintra ${ }^{2}$. Como é sabido, esta novela foi escrita a catro mans por Eça de Queiroz e Ramalho Ortigão. Decidimos traballar este aspecto porque a nosa experiencia na tradución do par de linguas portugués-castelán nos ensinou que a tradución do infinitivo flexionado é un aspecto crítico e coidamos que sería interesante afondar no estudo desta cuestión observando e analizando unha tradución coa calidade da que nos deixou Carmen Martín Gaite, para observar o catálogo de recursos que se poden utilizar para traducir o infinitivo flexionado.

Coidamos que o estudo dun aspecto como este ten abondo interese para os tradutores que enfrontan as dificultades que presenta o transvase desta forma verbal no par de linguas portugués-castelán.

O infinitivo flexionado é unha das áreas críticas da gramática do portugués. Isto débese a varias razóns de orde diversa. En primeiro lugar, hai que sinalar o homomorfismo que se dá entre o infinitivo non flexionado, a primeira e a terceira persoa do infinitivo flexionado, e entre o paradigma do infinitivo flexionado e o do futuro do subxuntivo dos verbos regulares. Unicamente non hai formas homógrafas nestes dous tempos na maioría dos verbos irregulares, como veremos. Este aspecto resultou ser dunha importancia decisiva no desenvolvemento deste traballo á hora de distinguir as formas do infinitivo flexionado das do futuro do subxuntivo. Para exemplificar esta cuestión damos de seguida un exemplo tomado do estudo «A Flexão Verbal do Português (Estudo de morfologia histórica)» de Joseph-Marie Piel (publicado en 1944): «cantar [...] se usa hoje com triplo valor: o de infinitivo, de infinitivo pessoal e de futuro do conjuntivo» (Piel 1989: 214). En segundo lugar, a delimitación de funcións entre o infinitivo non flexionado e o flexionado é, frecuentemente, moi tenue. Repárese que moitas veces o infinitivo flexionado é substituíbel pola forma non flexionada sen que se altere o sentido da frase. Isto crea problemas á hora de distinguir o infinitivo flexionado do non flexionado, salvo que a forma verbal teña suxeito explícito como no seguinte exemplo: (1) Era bom ele vir connosco. En casos como (1) ao pormos a frase nunha persoa do verbo que non sexa a primeira (1p) ou a terceira (3p) do singular, vemos de forma clara que se trata dun infinitivo flexionado: (2) Era bom tu vires connosco.

Para concluírmos esta nota introdutoria, hai que sinalar, asemade, que o estudo desta cuestión ten tamén interese para a lingua galega, aínda que de xei-

1 Este artigo é un resumo do Traballo de Fin de Mestrado dirixido pola profesora e tradutora Ana Hermida Ruibal e presentado no verán de 2017 no ámbito do Mestrado en Tradución para a Comunicación Internacional impartido na Universidade de Vigo.

2 Ao longo do presente traballo referirémonos a esta obra usando o título completo, a abreviatura do mesmo creada a partir da primeira letra dos substantivos que o constitúen (MES) o simplemente como то (Texto Orixinal). A tradución desta obra é mencionada usando o título completo ou ben a abreviatura TT (Texto Traducido). 
to indirecto. Isto porque, como se sabe, o infinitivo flexionado forma parte do paradigma verbal do galego, porén, o uso deste tempo tan característico do galego e do portugués ten recuado nas últimas décadas, no galego falado e tamén no escrito como constatan varios lingüistas (Freixeiro 2000: 389-391; Gondar 1978). Este panorama contrasta coa vitalidade que esta forma verbal ten en portugués, sobre todo no portugués europeo (Cunha 2002: 486).

\section{II.- OBXECTIVOS}

O principal obxectivo deste traballo é establecer e estudar cales son os medios de expresión que se utilizan en castelán para traducir a forma flexionada do infinitivo, tamén denominado infinitivo conxugado ou persoal ${ }^{3}$ do portugués. Para iso, analizamos o modo como foi traducido o infinitivo flexionado na versión castelá d'O Mistério da Estrada de Sintra elaborada por Carmen Martín Gaite e que se publicou por primeira vez en 1974. O infinitivo flexionado, polas razóns anteriormente expostas, soe ser un elemento problemático cando se fai unha tradución do portugués ao castelán, xa que este idioma, como xa foi referido, carece da devandita forma verbal. Abrolla, deste xeito, no proceso de tradución un baldeiro que temos que encher e para iso hai que atopar os recursos que permitirán salvar este obstáculo e, ao mesmo tempo, facer que o resultado da tradución (o produto) semelle o máis natural posíbel e sexa aceptábel para o lector da cultura receptora da tradución en causa.

Como veremos, non é nosa intención elaborar un catálogo de cariz prescritivo de como se debe traducir o infinitivo flexionado ao castelán. Non obstante, o que se pretende con este traballo é analizar os recursos utilizados para obter unha tradución equivalente dos anacos de texto sacados da obra obxecto da nosa análise que conteñen formas do infinitivo flexionado e establecer as correspondencias entre o texto orixinal (то) e o texto traducido (Тт).

Nótese que no presente traballo se estableceu a distinción entre infinitivo flexionado ou conxugado, que non existe en castelán, e o infinitivo que aquí denominamos «persoal». Sinalar aínda que, como xa se indicou, non hai infinitivo flexionado en castelán pero, en cambio, si atopamos casos de infinitivo persoal nese idioma. Autores como Matte Bon rexistran o emprego do infinitivo en castelán con suxeito propio: ¿Tu padre llamar a mi madre? Sería una locu$r a$. (Matte Bon 2009: 78). Se ben que este autor recoñece que estaremos perante casos excepcionais. Na mesma liña apuntan traballos como, por exemplo, o de Fidalgo Enríquez (2011: 60-79).

Por outra parte, autores como Freixeiro Mato ou Gondar indican que o infinitivo flexionado vai camiño de converterse nunha forma obsolescente (Crystal 2000; Dorian 1981) no galego contemporáneo. Nese sentido, parécenos relevante facer este tipo de traballo para alertarmos sobre a necesidade de reincor-

3 A denominación «persoal» para o infinitivo flexionado parécenos que pode inducir a algunha confusión, pois hai, como veremos, infinitivos non flexionados que fan referencia á persoa que realiza a acción. 
porar o infinitivo flexionado no paradigma verbal do galego contemporáneo. Parécennos clarificadoras as palabras de Xosé Ramón Freixeiro Mato cando di:

[T]anto o infinitivo flexionado como o futuro do Subx. manteñen hoxe, no caso concreto do galego, unha especial relación canto ao seu uso, pois ambos se converteron en trazos morfosintácticos simbolicamente delimitadores dunha práctica lingüística autenticamente galega (galego-portuguesa) ou galegocastelá, marcada, respectivamente, pola súa presenza ou pola ausencia no discurso oral e fundamentalmente escrito. [...] Xa Rafael Dieste lles recomendaba aos autores con vocación literaria a fórmula "lingua popular + premeditación", pois non todo o popular ou "enxebre" é para el merecedor de se incorporar á lingua literaria (Freixeiro 2000: 389).

Esta premeditación que xa Rafael Dieste recomendaba aos escritores galegos é hoxe máis pertinente que nunca se se quere acadar esa autenticidade, esa afouteza que sinala Freixeiro Mato.

Polo anteriormente exposto, coidamos que este traballo pode tamén indicar vieiros menos batidos hoxe aos falantes de galego. Isto é, permitirá debullar algúns dos recursos dispoñíbeis en castelán e cales son os existentes en portugués e, por conseguinte, en galego, pois desde os albores do idioma o infinitivo flexionado é empregado do mesmo xeito, con pequenas diferenzas, aquén e alén Miño. Neste ámbito, a comparanza entre galego e portugués parécenos pertinente e poderá arroxar algunha luz sobre se de feito o galego está abdicando desta forma verbal por cuestións internas ou se, efectivamente, se trata dunha orientación evolutiva da lingua dominante (o castelán) a que determina esta mudanza en galego. Pese a que son varios os autores que apuntan como causa principal do retroceso no emprego do infinitivo flexionado en galego a interferencia do castelán, tal como se afirma nestas palabras de Xosé Feixó Cid, achamos que sería pertinente profundar o estudo deste aspecto facéndoo sen ser reféns de xuízos a priori:

En relación co infinitivo persoal ou conxugado, existente só en galego e portugués, hai que dicir que o mal uso deste débese sempre á influencia castelá, polo descoñecemento debido á súa inexistencia nesta lingua, de xeito que ás veces non se pode conxugar en galego o infinitivo, como cando este forma parte dunha perífrase verbal (así non é posible dicir os rapaces foron beberen, xa que habería que utilizar o infinitivo sen conxugar, beber). En xeral, digamos que non se pode empregar a forma conxugada, para indicar a persoa, cando esta xa aparece indicada con outra forma verbal que ten desinencias persoais (Feixó 2005: 194).

Falta nas palabras de Feixó, na nosa opinión, lembrar a outra face do problema: o escaso emprego das formas flexionadas do infinitivo que se verifica no galego contemporáneo. Ten que determinarse en que grao isto ocorre, e para iso haberá que facer, por unha parte, un estudo diatópico e, por outra, a comparanza co que sucede no portugués e no castelán neste eido, así como analizar o 
que ocorre en galego coas formas que se utilizan para substituír o infinitivo flexionado no seu ámbito de uso tradicional.

A pertinencia de estudar o infinitivo flexionado e do recuperar no galego de hoxe non é só importante no eido da literatura. É tamén, na nosa opinión, un sinal importante para frear o proceso de substitución lingüística que paira sobre o idioma de Rosalía. Son varios os autores que refiren a importancia dos procesos gramaticais, léxicos, morfolóxicos e tamén os procesos sociais en contextos de linguas en contacto en que unha delas ten un papel preponderante desde o punto de vista sociolingüístico ou maior prestixio que a lingua subordinada. Nese sentido parécennos esclarecedores estudos como o de Nancy Dorian (1981) sobre o gaélico escocés onde se enumeran e analizan exemplos de como a obsolescencia de determinados elementos lingüísticos é un indicador, un sinal de alerta, que precede a extinción dun idioma.

Con todo, non sendo este o obxectivo primordial deste estudo, parécenos que poderá contribuír a unha mellor comprensión do devandito fenómeno no galego contemporáneo. Esbozamos esta cuestión, como diciamos, sen xuízos previos á análise dos datos, pois é sabido que no portugués de Brasil, por exemplo, o infinitivo flexionado goza de menos vitalidade na oralidade que no portugués europeo, como ben explican Celso Cunha e Lindley Cintra na Nova Gramática do Português Contemporâneo 4 .

A finais dos anos setenta, Gondar constataba que no galego, tanto nos textos literarios como na oralidade, o infinitivo flexionado se usaba xa con menos frecuencia e de maneira máis restrinxida se o comparásemos cos usos documentados nos textos medievais e co emprego que ten no portugués de hoxe (Gondar 1978: 137-140). O citado autor deixaba entrever que pode haber certo paralelismo entre as restricións ao uso do infinitivo flexionado e o grao de castelanización do falante. Gondar refería tamén que o infinitivo flexionado se usaba case exclusivamente en oracións adverbiais (1978: 140). Este estudoso constatou que nos textos medievais o infinitivo flexionado é máis frecuente nos textos literarios que noutro tipo de documentos textuais (1978: 154-155).

$4 \ll \mathrm{O}$ uso do infinitivo flexionado parece ser mais frequente no português europeu do que no Brasil em razão da vitalidade, em Portugal, do tratamento tu e, por consequência, da flexão correspondente a esta pessoa no infinitivo pessoal. Predominando na maior parte do Brasil o tratamento íntimo você, que se constrói como o verbo na $3 .^{a}$ pessoa do singular - pessoa desprovida de desinência, ou melhor, com desinência zero $\varnothing-$, daí decorre a identificação desta forma no infinitivo pessoal com a do impessoal» (Cunha, 2002: 486).

Esta idea atopámola noutros autores, como por exemplo Vázquez Cuesta e Mendes da Luz:

«O uso do infinitivo flexionado português, chamado vulgarmente infinitivo pessoal, é um dos assuntos mais difíceis da sintaxe portuguesa. Podemos dizer que o infinitivo flexionado se utiliza em todas as construções sintáticas em que se pode empregar o infinitivo comum, à exceção daquelas em que este não admite sujeito. A escolha na prática dum ou doutro infinitivo costuma ter valor estilístico e ser determinada pelo interesse do falante em fazer ressaltar o sujeito, quer por clareza quer por ênfase» (Vázquez, 1971: 529-530).

Esta posibilidade de substituír a forma flexionada pola non flexionada na maioría dos contextos torna moi difícil na práctica distinguir a primeira e terceira persoa do infinitivo persoal da forma non flexionada. 
O feito de que o emprego na lingua oral sexa menos frecuente parece coincidir co que ocorre en portugués (Hampejs 1959: 188 e 1959/1960: 116). Semella tamén que é máis frecuente na prosa que en verso (Hampejs 1959: 188 e 1959/1960: 116).

\section{III.- METODOLOXÍA}

Acabamos de expor que o obxectivo primordial do noso traballo é determinar cales son o recursos que se utilizan en castelán para traducir o infinitivo flexionado portugués, xa que, como vimos, o castelán carece de flexión no infinitivo. Interesa, pois, saber que recursos desempeñan en castelán as funcións que o infinitivo flexionado posúe en portugués.

Con ese propósito, escolleuse a tradución d'O Mistério da Estrada de Sintra para realizar unha análise a nivel microestrutural. Trátase dun estudo descritivo que pretende formular leis de comportamento tradutivo, non no sentido prescritivo do termo, se non que se tenta establecer cal é o conxunto de leis de comportamento tradutivo que rexen o proceso de tradución no caso que nos ocupa. Nótese que se trata de leis que pretenden predicir comportamentos, por iso son leis de natureza probabilística, como sinalou Gideon Toury (1995: 264).

A razón pola que se optou por analizar O Mistério da Estrada de Sintra e, en concreto, a tradución de Carmen Martín Gaite é, por unha parte, porque se trata dunha novela escrita por dous dos autores máis destacados da literatura portuguesa do século XIX e, por outra, porque a tradución castelá da escritora e tradutora salmantina de orixe galega é de gran calidade, como testemuñan as numerosas edicións que vén tendo desde que se publicou esa versión por primeira vez en 1974.

A premisa é identificar os aspectos dos sistemas lingüísticos que interveñen no proceso de tradución e inflúen na toma de decisións durante ese mesmo proceso e explicar que factores interviñeron na toma dunha decisión concreta. Dito doutro modo, en que medida as características dos sistemas lingüísticos en contacto durante o proceso de tradución teñen influencia nas decisións e as opcións do tradutor, sen esquecer que hai outros factores determinantes para alén deste.

Para acadar ese obxectivo entendemos aquí o texto de partida e o de chegada como dúas faces dunha mesma moeda. O que Harris, entre outros autores, denomina de bi-textos: «a single text in two dimensions, each of which is a language» (Harris 1988: 9). Por iso, presentaremos os textos aliñados e analizaremos о то е о тт desde o punto de vista da equivalencia translémica (Corpas 1997) ou, segundo a nomenclatura que seguiremos aquí, transposición (Newmark 2006: 122). Temos conciencia das limitacións deste tipo de traballos, e máis cando se fan cun corpus tan pequeno, pero coidamos que é a única maneira de ir construíndo o aparello teórico que permitirá ir superando un grave problema dos Estudos de Tradución, o da falta dun modelo teórico axeitado; caren- 
cia esa que vén sendo apuntada nas últimas décadas por moitos autores ${ }^{5}$, como por exemplo, Rosa Rabadán.

Entendemos aquí a tradución como un proceso, un produto e unha función. Así, o que se pretende con este traballo é facer unha descrición dunha tradución concreta e extraer conclusións que nos permitan mellorar o proceso e o produto, sen afán prescritivo, pero si descritivo e preditivo, como xa foi explicado. Sen esquecermos que a función esencial de toda tradución é vehicular, transvasar uns contidos determinados dun sistema lingüístico $\mathrm{X}$ e da súa cultura a outro sistema lingüístico $\mathrm{Y}$ e o respectivo sistema cultural ${ }^{6}$.

Unha vez feita a extracción das formas verbais candidatas a infinitivos flexionados comprobouse que se trataban efectivamente de infinitivos flexionados. Nun primeiro momento aplicando os criterios que se enumeran deseguida para distinguir, por unha parte, as formas do infinitivo flexionado das formas do futuro do subxuntivo que aparecen no texto. As gramáticas de portugués presentan de diversos xeitos os casos en que se emprega o infinitivo flexionado, mais a descrición que nós seguimos aquí é a da Nova Gramática do Português Contemporâneo, por ser a máis clara e completa de todas as que analizamos?

5 «Hasta la fecha no existe modelo alguno que haya conseguido dar el salto definitivo: ir más allá de la descripción y sistematización de los factores que intervienen en el proceso de traducción para explicar cómo se produce el transvase lingüístico-textual de una cultura a otra. Las razones por las que no existe un modelo tal son obvias. No disponemos de investigaciones consolidadas en multitud de campos que participan en el área interdisciplinar de la traducción» (Rabadán 1991: 31).

6 Aínda que quede de fóra do ámbito do noso estudo, coidamos que non se debe esquecer un aspecto que ten dominado nas últimas décadas os Estudos de Tradución: a cuestión da recepción dunha tradución na cultura meta e a influencia que ten nesa cultura receptora. Dese modo, teremos que ver cal é a recepción e aceptación que ese texto ten na cultura de chegada, isto é, temos que situalo no polisistema (Even-Zohar 1990: 45-51) ao que pertence e no que é percibido como texto traducido. Sobre esta cuestión falaremos no apartado 5 titulado «A tradución de Carmen Martín Gaite d'O Mistério da Estrada de Sintra», aínda que sucintamente, pois non é ese o obxectivo primordial do presente traballo. Para elaborar a lista dos infinitivos flexionados que aparecen no corpus procedeuse a unha extracción manual e despois fíxose unha verificación coa ferramenta «buscar» nun documento pdf da obra que constitúe o noso corpus: O Misterio da Estrada de Sintra. A versión en pdf presenta moi poucas diferenzas en comparación coa versión en papel que utilizamos para extraer os infinitivos persoais e tamén as citacións que se fan neste traballo por parecérennos a versión editada por Livros de Brasil (en papel) máis fiábel que a que está dispoñíbel na Internet

7 As gramáticas que consultamos para comprobar os usos do infinitivo flexionado en portugués foron:

Ali, Said (s./d.), Gramática secundária da língua portuguesa. São Paulo: Melhoramentos.

Celso Cunha e Lindley Cintra (2002,17.a ed.) Nova Gramática do Português Contemporâneo. Lisboa: João Sá da Costa.

Ferreira, A Gomes e J. Nunes de Figueiredo (2006) Compêndio de Gramática Portuguesa. Porto: Porto Editora.

Neves, Maria Helena de Moura (2000) Gramática de Usos do Português. São Paulo: Editora UNESP

VV.AA. (2003) Gramática da Língua Portuguesa. Lisboa: Editorial Caminho. 
Os candidatos a infinitivos flexionados foran sometidos ás seguintes análises e transformacións:

$1^{\circ}$ ) Consideramos infinitivos flexionados aquelas formas verbais que admiten a substitución por unha forma verbal finita ${ }^{8}$ :

No momento de partirmos, o que ia guiar bateu na vidraça e pediu um charuto (MES, 23). > [No momento em que partimos, o que ia guiar bateu na vidraça e pediu um charuto].

Non obstante, en casos como:-Bem me queria a mim parecer que a casa do lado também tem... (MES: 80). Non é posíbel facer esta transformación co infinitivo parecer, o que é sinal de que se trata da forma non flexionada do infinitivo. Este procedemento, aínda que non é infalíbel, permitiu resolver un número considerábel de casos en que o infinitivo flexionado, como carece de desinencias na primeira e na terceira persoas do singular, se confunde co infinitivo non flexionado, pois nestes casos estamos perante formas homógrafas.

$2^{\circ}$ ) Por outra parte, para resolver as dúbidas que provoca o feito de o futuro do subxuntivo e o infinitivo flexionado teren formas homógrafas nos verbos regulares, o que é fonte de algunha confusión á hora de distinguir unhas das outras. A solución que atopamos foi substituír, sempre que era posíbel, o verbo regular por un verbo irregular (a maioría ten formas diferentes no infinitivo flexionado e no futuro do subxuntivo) nos casos en que a homografía xeraba dúbidas, por exemplo:

Não me lembra o resto. Se as pessoas que passaram, tocando e cantando, lerem esta carta, prestarão um notável esclarecimento dizendo em que rua passavam, e defronte de que casa, quando cantaram aquelas rimas populares (MES: 39).

Se substituímos lerem por un verbo co futuro de subxuntivo conxugado de forma irregular como fazer ou ter, observamos que, ao trocarmos de verbo, a frase resultante é agramatical pero, en cambio, co futuro de subxuntivo si obtemos unha frase gramatical e aceptábel, como se pode constatar no exemplo seguinte:

Não me lembra o resto. Se as pessoas que passaram, tocando e cantando, [trat / tiverem, fizerem] lerem esta carta, prestarão um notável

8 Esta característica dos infinitivos flexionados xa foi sinalada no século XIX Friedrich Christian Diez (1794-1876) na obra Grammatik der romanischen Sprachen:

A gramática portuguesa possui uma característica especial na flexão autenticamente verbal do infinitivo [...] concede ao infinitivo uma flexão inteiramente verbal para designar as relações pessoais, sem que este modo, de forma alguma, se transforme num verdadeiro tempo, como o provam as preposições que lhe são antepostas. Contudo este infinitivo só se usa quando se pode desligar da sua dependência do verbo principal. É indiferente que tenha ou não sujeito próprio (citamos a partir de Huber, 2006: 208). 
esclarecimento dizendo em que rua passavam, e defronte de que casa, quando cantaram aquelas rimas populares (MES: 39).

Por outra parte, nas «formas perifrásticas» (Vázquez, 1971: 530) nas que o suxeito do infinitivo vén determinado polo verbo auxiliar «que lhe completa a significação, sempre que não medeie entre os dois verbos grande distancia» (Vázquez, 1971: 530), foron consideradas formas non flexionadas.

Xunto a estas transformacións e comprobacións aplicamos os criterios establecidos por Cunha e Cintra (2002: 485-487) e Vázquez Cuesta e Mendes da Luz (1971: 532-534) que veremos no apartado 6.3. O emprego da forma flexionada do infinitivo.

\section{IV.- O MISTÉRIO DA ESTRADA DE SINTRA}

Esta obra é un bo exemplo do esforzo e a constancia que tivo unha xeración de intelectuais, artistas e escritores portugueses para mudar a sociedade portuguesa mediante a reflexión e a crítica dos costumes; a esa xeración pertencían José Maria Eça de Queiroz (1845-1900) e José Duarte Ramalho Ortigão (18361915). Carlos Reis resume O Mistério da Estrada de Sintra do seguinte modo:

[E]sa especie de aventura literaria [...] en la que se cruza lo enigmático de extracción romántica, el satanismo de coloración decadentista (representado en Fradique Mendes, que reaparece aquí), el entramado propio del relato policial y el análisis de costumbres sociales (Gavilanes 2000: 435-436).

Estamos perante unha novela que, pese aos defectos que se lle poidan apuntar, quería espertar a sociedade portuguesa da época. Así o constatan os autores, Eça e Ortigão, en 1884, catorce anos despois da publicación da obra en formato de folletín no Diário de Notícias (1870) quen, ademais de sinalar todos os defectos que o paso do tempo destapou, segundo eles, indican tamén a principal motivación que os levou a redactar esta obra, axitar, espertar a sociedade portuguesa daquel período 9 .

\section{V.- A TRADUCIÓN DE CARMEN MARTÍN GAITE D'= MISTÉRIO DA ESTRADA DE SINTRA}

Carmen Martín Gaite (1925-2000) foi unha figura destacada da literatura española do século xx. Autora dunha vasta produción literaria nos eidos da narrativa, o ensaio, a poesía e o teatro. O seu labor estendeuse tamén ao ámbito

\footnotetext{
9 «Há catorze anos, numa noite de Verão, no Passeio Público, em frente de duas chávenas de café, penetrados pela tristeza da grande cidade que em torno de nós cabeceava de sono ao som de um soluçante post-pourri dos Dois Foscaris, deliberámos reagir sobre nós mesmos e acordar tudo aquilo a berros, num romance tremendo, buzinado à Baixa das alturas do Diário de Notícias» (MES: 11).
} 
da tradución, onde traduciu diversas obras de autores de referencia da literatura universal como Charlotte Brontë, Alfau, Virginia Woolf, Gustave Flaubert e, ente outros moitos ${ }^{10}$, O Mistério da Estrada de Sintra de José Maria Eça de Queiroz e José Duarte Ramalho Ortigão.

Achamos que a tradución de Martín Gaite ten moita calidade; proba diso é que, aínda hoxe, a versión castelá desta escritora é a que seguen a maioría das edicións en castelán ${ }^{11}$ que se veñen publicando nas últimas décadas deste clásico da literatura portuguesa. Estamos perante un texto fundamental da literatura portuguesa do XIX cuxa tradución entrou no sistema literario hispánico e consagrouse, con relativo éxito, como obra precursora e de referencia da literatura de cariz policial, xa que $O$ Mistério da Estrada de Sintra é unha obra bastante orixinal nese sentido e que renovou este xénero literario, polo menos no contexto ibérico.

Como dicíamos, Martín Gaite realizou numerosas traducións ao castelán de obras eminentes da literatura universal como Jane Eyre de Charlotte Brontë (obtivo por este traballo o premio de tradución Ángel Créspo a título póstumo poucos meses despois do seu pasamento), Madame Bovary de Gustave Flaubert, Al Faro de Virginia Wolf, El Marinero de Fernando Pessoa, Cuentos de Perrault de Charles Perrault, entre outros moitos.

Di Santos Sanz Villanueva que na obra de Martín Gaite «Las fronteras entre la novela y otro tipo de libro de difícil clasificación -mezcla de autobiografía, fícción y ensayo- se hacen cada vez más delgadas en Martín Gaite» (Sanz, 1984: 118). Esta característica da obra narrativa de Gaite pode axudar a entender o interese que espertou á autora O Mistério da Estrada de Sintra, obra onde se funden de forma orixinal diversos xéneros literarios.

Martín Gaite recibiu unha bolsa para estudar en Coimbra no verán de 1946, cando contaba 21 anos. Nesa viaxe visitou Lisboa e Porto, e contactou por primeira vez coa literatura portuguesa. Desa experiencia son debedoras a tradución obxecto deste estudo e o ensaio Adulterio y chantaje en «El primo Bazilio».

Como non podería ser doutro xeito, a experiencia vital de Carmen Martín Gaite deixou fonda pegada na súa obra literaria. Bo exemplo disto é a súa estreita relación con Galiza. Martín Gaite era filla de galega, a súa nai era natural de San Lorenzo de Piñor (Ourense), onde pasou os veráns da súa infancia. Este vencello con Galiza está presente en diversas obras da autora, como: Las

10 Véxase a bibliografía elaborada polo servizo de Bibliotecas e Documentación do Instituto Cervantes en Instituto Cervantes (s.d.) Bibliografía de Carmen Martín Gaite, dispoñible en http:// www.cervantes.es/imagenes/File/martin_gaite_biblio.pdf

${ }_{11}$ Atopamos dúas traducións da novela de Eça de Queiroz e Ramalho Ortigão anteriores á de Carmen Martín Gaite:

El Misterio de la Carretera de Cintra (1946). Trad. Julio Gómez de la Serna. Madrid: M. Aguilar.

El Misterio de la Carretera de Cintra (1937). Trad. A. González-Blanco. Madrid: Biblioteca Nueva. 
ataduras (1959); na novela Retahílas (1974); El cuarto de atrás (1978), por dar apenas algúns exemplos (González, 2009).

Este coñecemento da literatura portuguesa, da lingua e da cultura do país veciño contribuíron, sen sombra de dubida, á elevada calidade que presenta a versión d'O Mistério da Estrada de Sintra que Carmen Martín Gaite elaborou.

\section{VI.- O INFINITIVO FLEXIONADO}

As formas verbais finitas son aquelas cuxo verbo se encontra flexionado, isto é, ten morfema de tempo, modo, número e persoa. O infinitivo flexionado é unha forma verbal non finita porque carece de morfema temporal, pero que conta con flexión de número e persoa. As outras formas verbais non finitas do verbo, no caso do portugués, son o infinitivo non flexionado, o xerundio e o participio pasado (Vilela, 2009: 99). Isto significa que o infinitivo flexionado, a pesar de ser considerado unha forma non finita, participa nalgunhas características das formas finitas, concretamente na flexión en número e persoa.

Celso Cunha e Lindley Cintra lembraban que a distinción entre as formas de infinitivo flexionadas e non flexionadas en portugués é unha das cuestións máis controvertidas entre os estudosos da gramática desa lingua ${ }^{12}$.

Como veremos máis adiante, o infinitivo é unha categoría que engloba formas verbais moi diversas entre si desde o punto de vista semántico e sintáctico. Hai casos en que o infinitivo, mesmo a forma persoal, admite o artigo, flexión de número e outros determinantes propios do substantivo, desempeñando na oración as funcións propias dun substantivo (Já lestes os dizeres da parede), tanto é así que nos dicionarios de portugués «dizer» conta cunha entrada como substantivo. Outras veces se atopa máis próximo ao verbo (Depois de falar com ele ficaram mais descansados); neste exemplo o infinitivo vai determinado polo adverbio depois. Por todo o anteriormente exposto, resulta evidente que estamos perante un elemento lingüístico complexo e, nalgúns aspectos, difícil de clasificar.

\subsection{Orixe}

A orixe do infinitivo flexionado en portugués (e galego) é aínda un tema que xera algunha controversia entre os lingüistas. Por unha parte, hai os que defenden que o infinitivo flexionado derivou do imperfecto do subxuntivo latino (Ferreira \& Figueiredo 2006: 203; Piel 1989: 214).

12 «Numerosas têm sido as regras propostas pelos gramáticos para orientar com precisão o uso selectivo das duas formas. Quase todas, porém, submetidas a um exame mais acurado, revelaram-se insuficientes ou irreais. Em verdade, os escritores das diversas fases da língua portuguesa nunca se pautaram, no caso, por exclusivas razões de lógica gramatical, mas viram-se sempre, no acto da escolha, influenciados por ponderáveis motivos de ordem estilística, tais como o ritmo da frase, a ênfase do enunciado, a clareza da expressão» (Cunha, 2002: 482). 
Por outra parte, hai quen defenda que xurdiu debido á «confusão fácil entre o infinitivo e algumas formas do subjuntivo futuro» (Maurer, 1968: 13). Sexa como for, parécenos evidente que esta forma verbal aparece para colmar unha necesidade expresiva dos falantes; sinalar a persoa á que se refire o infinitivo. Con todo, a explicación de Piel, que de seguida amosamos, parécenos a máis plausíbel á luz do que hoxe sabemos, e é un resumo bastante clarificador desta hipótese que nós compartimos:

[S]abemos que foi, entre outras circunstâncias, o uso do imperfeito do conjuntivo em orações subordinadas sem auxilio de conjugações (tipo PLACUIT [UT] FACEREM) que contribui decisivamente para a génese do infinitivo pessoal. Por outro lado, a coincidência formal de *FACËRE com FACËREM e FACĒRET (devida ao emudecimento de -M e -T finais), fez com que, em construções do tipo PLACUIT MIHI FACEREM, frequentes nos mais antigos documentos latino-portugueses, se interpretasse o infinito como dizendo respeito a uma determinada pessoa. Foi isto o suficiente para sugerir fazeres, fazermos, etc., quer dizer, unha flexão pessoal do infinito (Piel, 1989: 237).

Se ben que, como afirma Hampejs, a «identidade das desinências do futuro do conjuntivo e do infinitivo conjugado salta à vista, e desta maneira o futuro do conjuntivo, no nosso entender, apesar de não ser a origem do infinitivo, pode influir para acelerar o processo da sua criação» (Hampejs, 1959: 182-183).

Trátase, por tanto, dun fenómeno antigo, presente xa na xénese do romance que despois deu lugar ao galego e ao portugués. É moi probábel que esteamos perante unha tendencia que terá xurdido xa no latín hispánico que se falaba no occidente da Península Ibérica antes da eclosión das variedades románicas que hoxe coñecemos. Hai que salientar que, aínda que moitas veces se fale do infinitivo flexionado como algo exclusivo do portugués e do galego, a verdade é que tamén se atopaba no astur-leonés, de feito aínda goza de moita vitalidade no mirandés e está abondo documentado en textos en astur-leonés medieval (Lorenzo, 2016: 44-47), hai noticia desta forma verbal dentro do ámbito románico no napolitano do século XV (Freixeiro, 2000: 389) e fóra del no húngaro.

\subsection{Morfoloxía}

O infinitivo flexionado ten as mesmas desinencias de número e persoa para as tres conxugacións, como se pode observar na táboa seguinte: 
TÁBOA 1: FORMAS DO INFINITIVO FLEXIONADO SIMPLE PARA AS TRES CONXUGACIÓNS.

\begin{tabular}{|l|l|l|}
\hline $\begin{array}{l}\text { Infinitivo non } \\
\text { flexionado }\end{array}$ & $\begin{array}{l}\text { Desinencia } \\
\text { número-persoal }\end{array}$ & Exemplo \\
\hline Cantar & $\varnothing$ & Cantar \\
\cline { 2 - 3 } Viver & -es & Cantares \\
\cline { 2 - 3 } Partir & $\varnothing$ & Cantar \\
\cline { 2 - 3 } Ter & -mos & Cantarmos \\
\cline { 2 - 3 } Estar & -des & Cantardes \\
\cline { 2 - 3 } Haver & -em & Cantarem \\
\hline
\end{tabular}

O infinitivo flexionado non debe confundirse co futuro do subxuntivo, tempo verbal que posúe, nos verbos regulares, as mesmas formas que o infinitivo flexionado. Pola contra, nos verbos irregulares estes dous tempos verbais contan con formas diferentes (por exemplo no caso de verbos como dar, ter, ir, querer, poder ou saber). Vexamos o verbo ter nos dous tempos en causa:

TÁBOA 2: COMPARANZA ENTRE AS FORMAS DO INFINITIVO FLEXIONADO E O FUTURO DO SUBXUNTIVO EN PORTUGUÉS.

\begin{tabular}{|l|l|l|}
\cline { 2 - 3 } \multicolumn{1}{c|}{} & Infinitivo flexionado & Futuro do subxuntivo \\
\hline eu & ter & tiver \\
tu & teres & tiveres \\
ele & ter & tiver \\
nós & termos & tivermos \\
vós & terdes & tiverdes \\
eles & terem & tiverem \\
\hline
\end{tabular}

O infinitivo flexionado admite tamén a forma composta que se constrúe xuntando a forma simple do verbo ter ao participio pasado do verbo conxugado. A forma composta do infinitivo achega información sobre o aspecto que non se atopa nas formas simples nin no infinitivo non flexionado. Esta información aspectual é achegada pelo verbo ter e en rexistros máis formais do idioma por haver, que expresa a noción de perfectividade patente no infinitivo flexionado composto: 
TÁBOA 3: FORMAS DO INFINITIVO FLEXIONADO COMPOSTO

\begin{tabular}{|l|l|l|l|}
\cline { 2 - 4 } \multicolumn{1}{c|}{} & \multicolumn{3}{l|}{ Infinitivo flexionado composto } \\
\hline eu & ter & + & falado \\
tu & teres & & vivido \\
ele & ter & & \\
nós & termos & & \\
vós & terdes & & \\
eles & terem & & \\
\hline
\end{tabular}

\subsection{Emprego $^{13}$}

Segundo os criterios establecidos por Celso Cunha e Lindley Cintra na Nova Gramática do Português Contemporâneo (2002: 485-486) emprégase a forma flexionada do infinitivo no casos que se sinalan deseguida:

1..$^{\circ}$ ) Cando hai un suxeito expreso:

Os trabalhadores pediram-me para eu falar com a administração.

Ou tamén:

Sem eu bem poder a esse tempo explicar porquê, não me parecia também que as pessoas que nos rodeavam projectassem um roubo, menos ainda um homicídio (MES: 22).

$2^{\circ} .^{\circ}$ Cando o infinitivo flexionado se refire a un axente non expreso que se quere tornar explícito por medio da desinencia verbal:

Acho má ideia deixares o teu carro.

Ou tamén:

Em seguida rangeu uma fechadura e transpusemos o limiar de uma porta, que foi outra vez fechada à chave depois de havermos entrado. (MES: 32).

3. ${ }^{\circ}$ ) Cando na $6 \mathrm{P}$ se sinala un suxeito indeterminado:

Ouvi dizerem que era boa pessoa.

4. $\left.{ }^{\circ}\right)$ Por motivos estilísticos, coa finalidade de dar á frase maior énfase ou harmonía:

13 Elaborouse este apartado a partir da Nova Gramática do Português Contemporâneo de Celso Cunha e Lindley Cintra, páxs. 485-487. 
Aqueles homens gotejantes de suor, bêbados de calor, desvairados de insolação, / a quebrarem, / a espicaçarem, / a torturarem a pedra, / pareciam um punhado de demónios revoltados na sua impotência contra o impassível gigante. (Azevedo, 1890: 66. Exemplo tomado de Cunha e Cintra, 2002: 486).

Para Said Ali, «a escolha da forma infinitiva depende de cogitarmos somente da acção ou do intuito ou necessidade de pormos em evidência o agente da acção» (Ali, s./d.: 180). Este carácter facultativo que presenta con frecuencia a forma flexionada do infinitivo é lembrado por outros autores como por exemplo Maria Helena de Moura Neves (2000: 341), ou os xa mencionados Celso Cunha e Lindley Cintra. Estes últimos conclúen que o emprego do infinitivo flexionado en portugués é selectivo e que se trata de un criterio «mais do terreno da estilística do que, propriamente, da gramática» (Cunha, 2002: 487).

\subsection{Valores sintácticos}

O infinitivo flexionado empregase en portugués tanto en oracións principais coma subordinadas, se ben parece ser máis frecuente neste último caso. As veces pode coexistir cun verbo conxugado (Fidalgo, 2011: 60).

O infinitivo flexionado pode constituír oracións subordinadas completivas, adverbiais finais, temporais, causais, concesivas, completivas, condicionais (Vázquez, 1971: 532-534). O infinitivo pode tamén realizar as funcións propias dun substantivo e desempeñar nese caso a función de núcleo do sintagma nominal. No apartado 8. «Análise dos tipos de transposición para traducir o infinitivo flexionado na edición castelá d'O Mistério da Estrada de Sintra» analizaremos cales son as funcións sintácticas que posúen os infinitivos extraídos do corpus. 


\section{VII.- ANÁLISE GLOBAL DOS INFINITIVOS FLEXIONADOS N'O MISTÉRIO DA ESTRADA DE SINTRA}

Rexistramos un total de 44 infinitivos flexionados na novela $O$ Mistério da Estrada de Sintra. Desas, 37 son formas simples e 7 compostas:

TÁBOA 4: DISTRIBUCIÓN DAS FORMAS SIMPLES E COMPOSTAS DO INFINITIVO FLEXIONADO N'O MISTÉRIO DA ESTRADA DE SINTRA (TO).

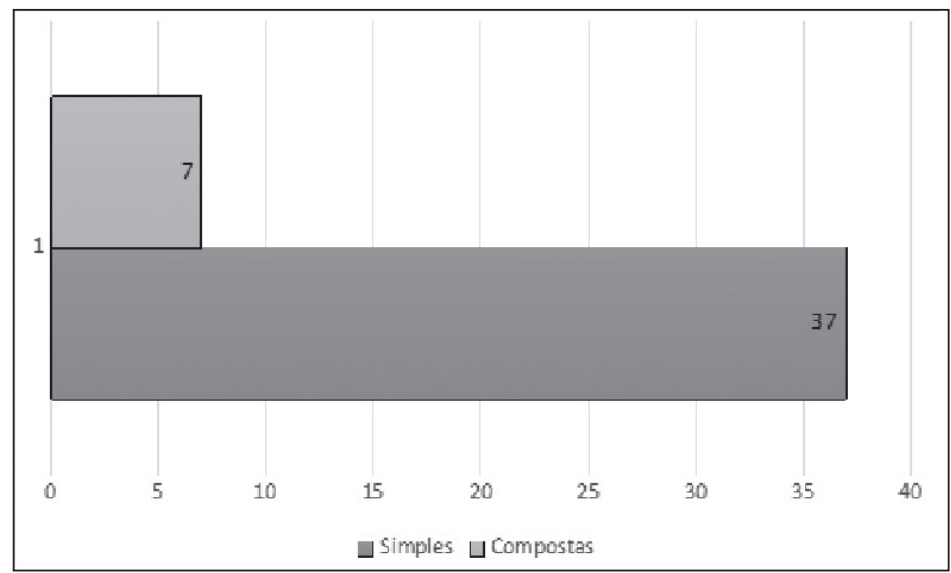

Por outra parte, hai que sinalar que a distribución das formas de infinitivo flexionado conforme á desinencia de número e persoa foi a seguinte:

TÁBOA 5: INFINITIVOS FLEXIONADOS SEGUNDO A DESINENCIA DE NÚMERO E PERSOA N’O MISTÉRIO DA ESTRADA DE SINTRA.

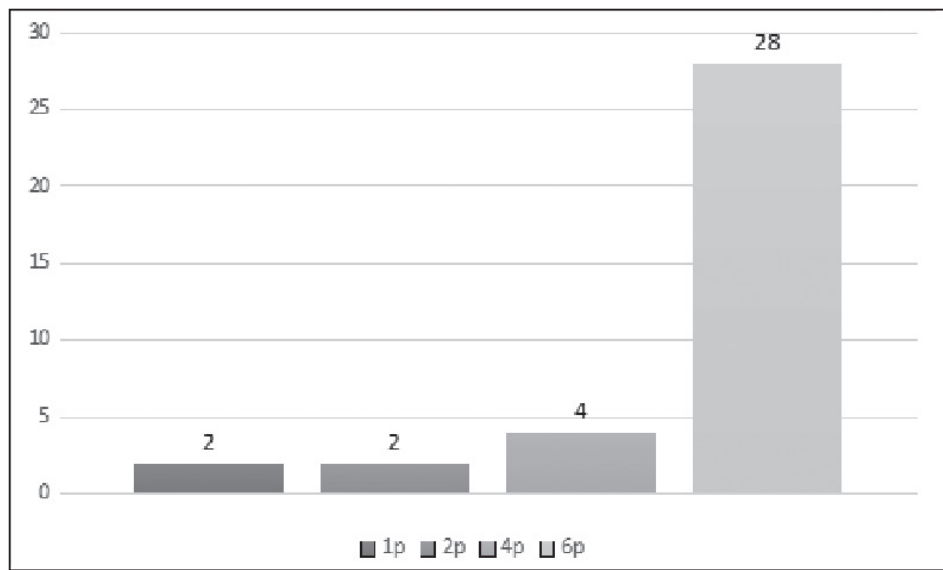


$\mathrm{Na}$ táboa anterior queda claro que os infinitivos flexionados na terceira persoa do plural (6p) son os máis frecuentes no corpus analizado (28 ocorrencias), seguidos de lonxe polos infinitivos flexionados da primeira persoa do plural (4p), que conta con 5 ocorrencias; en cambio, da primeira (1p) e da segunda ( $2 p)$ contabilízanse dúas formas de cada unha. Por outra parte, hai que sinalar a ausencia de formas na terceira persoa do singular. Tampouco se atoparon formas da segunda persoa do plural, o que parece indicar que o recúo do uso desta forma no portugués meridional de finais do século XIX xa arraigara de tal forma que até da escritura foi barrida por completo esta forma.

Outro dato que cómpre reter desta breve análise das ocorrencias do infinitivo flexionado no texto de partida é que a primeira e a segunda persoas do singular son pouco operativas, como se observa na táboa 5 onde se indica que hai dous casos da primeira persoa do singular e outros dous da segunda persoa do singular do infinitivo flexionado. Tras analizar as formas en infinitivo que atopamos no texto á luz dos criterios que referimos en apartados anteriores, só en dous casos somos quen de garantir que estaremos perante un caso claro de infinitivo flexionado na primeira persoa. $\mathrm{O}$ que nos fai pensar que a fronteira entre o infinitivo flexionado e o infinitivo non flexionado é moi difusa.

Porén, a escaseza de infinitivos flexionados na segunda persoa do singular ao longo do texto está relacionada, na nosa opinión, co feito de que en portugués, xeralmente, se interpela o lector na terceira persoa e non na segunda como é corrente en linguas como o inglés, o castelán e o galego. A explicación é, neste caso, de natureza completamente diferente ao caso da primeira e terceira persoas do singular, xa que moi probablemente nun outro tipo de texto a frecuencia de uso da segunda persoa será maior, mentres que a dificultade en separar as formas de primeira e terceira persoa prevalecerá.

Para concluír o presente apartado amosamos a distribución no corpus das formas de infinitivo flexionado composto:

TÁBOA 6: DiSTRIBUCIÓN DAS FORMAS DO INFINITIVO FLEXIONADO COMPOSTO SEGUNDO A DESINENCIA DE NÚMERO E PERSOA N'O MISTÉRIO DA ESTRADA DE SINTRA.

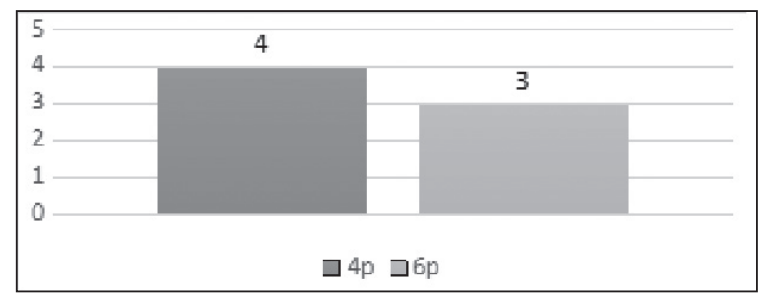

Mostra esta táboa que se contabilizaron 7 formas en total: 4 da segunda persoa do plural (4p) e 3 da terceira do plural (6p). 


\section{VIII.- ANÁLISE DOS TIPOS DE TRANSPOSICIÓN PARA TRADUCIR O INFINITIVO FLEXIONADO NA EDICIÓN CASTELÁ D'O MISTÉRIO DA ESTRADA DE SINTRA}

Vimos até o de agora o funcionamento do infinitivo flexionado, a súa orixe e os problemas de análise que esta forma verbal presenta. Indicouse tamén que o castelán carece desta forma verbal, o que significa que no proceso de tradución se dá o tipo de transposición (o que Catford denominou shift, en galego «cambio») en que, carecendo desa forma ou «estrutura gramatical» (Newmark, 2006: 122; Catford, 1965), o tradutor terá que encontrar alternativas para encher ese baldeiro. Newmark distingue tres tipos diferentes de transposicións: un primeiro tipo é aquel en que o tradutor realiza a transposición dun elemento do то ao тт «automáticamente - no tiene otro remedio- e incluiría el cambio del singular al plural (furniture: "muebles"; applause: "aplausos"; advice: "consejos"), o la posición del adjetivo ("la casa blanca": the white house)» (Newmark, 2006: 122). Un segundo tipo é o que nos ocupa aquí, cando una estrutura da lingua orixinal non existe na lingua da tradución e hai que buscar formas alternativas para suplir esa carencia. Newmark fala tamén dun terceiro tipo de transposición no que, sendo posíbel transvasar unha estrutura gramatical dunha lingua para outra, facer unha tradución literal, o uso da mesma talvez «choque con el uso natural de la lengua terminal» (Newmark, 2006: 123). Isto é o que acontece cando se traduce de forma literal a pasiva do portugués ao español: é posíbel gramaticalmente, mais non resulta natural na maioría dos casos, se ben que moitas veces depende do rexistro de lingua que esteamos a utilizar, por exemplo, o uso da pasiva en castelán soará máis natural nun texto escrito nun rexistro formal que na oralidade ou nun texto menos codificado.

\subsection{Transposición tipo 1 infinitivo flexionado $\rightarrow$ verbo no subxuntivo:}

Atopamos catro casos en que para a transposición do infinitivo flexionado se emprega en castelán un verbo conxugado no subxuntivo. Nun dos casos é un tempo composto (hubiera podido) e os outros tres preséntanse no pretérito imperfecto do subxuntivo (ocurrieran, fueran - estes dous aparecen na mesma frase- e sonrojasen). Nos catro casos constitúen oracións subordinadas:

TO

(3a) O olhar dos homens era-me insuportável: parecia-me envolver uma afronta.

Imaginava que era pública a aventura do meu coração, que era julgada como uma criatura de paixões fáceis, o que dava a todos o direito de me fazerem corar (páx. 232).
TT

(3b) No soportaba la mirada de los hombres: me parecía que encerraba una afrenta, que todos conocían mi asunto, que me juzgaban una mujer fácil y que me sonrojasen (páx. 228). 
Repárese que no exemplo anterior a tradutora une as dúas oracións nunha única oración complexa movendo algúns elementos: «O olhar dos homens» que esta nо то ao comezo da oración e no тт «la mirada de los hombres» desprázase cara á posición posverbal, pois resulta máis natural na lingua de chegada.

\subsection{Transposición tipo 2 infinitivo flexionado $\rightarrow$ Locución verbal:}

Segundo a Nueva gramática de la lengua española, non podemos considerar como perífrases os denominados: «ESQUEMAS FRASEOLÓGICOS SEMIPRODUCTIVOS. Se trata de combinaciones en las que el verbo en forma no personal es RESTRINGIDO LÉXICAMENTE, en el sentido de limitado a unos pocos verbos de determinada clase semántica» (Real Academia Española, 2010: 534-535). Por outra parte, na referida gramática sinálase que tampouco teñen carácter perifrástico as «LOCUCIONES VERBALES que los diccionarios incluyen como fórmulas fijas» (Real Academia Española, 2010: 535) como é o caso de (5b) que aparece no dicionario da Real Academia Española (DRAE) etiquetado como locución verbal ${ }^{14}$, aínda que nese dicionario non se indique a forma pronominal coidamos que se trata tamén dunha locución verbal, pois o pronome non provoca alteracións substanciais desde o punto de vista da clasificación destas palabras.

\begin{tabular}{|c|c|c|}
\hline TO & & TT \\
\hline $\begin{array}{l}\text { (5a) É certo que, dois minutos depois } \\
\text { de termos principiado }{ }^{15} \text { a andar, } \\
\text { me seria absolutamente impossível } \\
\text { decidir se ia de Lisboa para Sintra ou } \\
\text { se vinha de Sintra para Lisboa (páx. } \\
25 \text { ). }\end{array}$ & $\rightarrow$ & $\begin{array}{l}\text { (5b) Lo cierto es que a los pocos } \\
\text { minutos de habernos puesto en } \\
\text { marcha ya me habría resultado } \\
\text { absolutamente imposible discernir } \\
\text { si íbamos de Lisboa a Sintra o } \\
\text { veníamos de Sintra a Lisboa (páx. } \\
\text { 21). }\end{array}$ \\
\hline
\end{tabular}

Nótese que o valor aspectual do infinitivo flexionado é transferido ao TT mediante o recurso a unha perífrase incoativa, mentres que no то o valor aspectual se atopa no verbo principal.

\subsection{Transposición tipo 3 infinitivo flexionado $\rightarrow$ substantivo:}

Documentáronse no corpus tres exemplos deste tipo.

14 Real Academia Española (2014) Diccionario de la lengua española (23. ${ }^{a}$ ed.). [Marcha], recuperado de $<$ http://dle.rae.es/?id=ON4wO00 $>$.

$15 \mathrm{Na}$ edición en pdf figura começado. 
TO

(6a) Neste momento quantas sei eu que sofrem, que esperam, que mentem, possuídas de um sentimento, que pouco mais lhes dá do que a felicidade de serem desgraçadas!
TT

(6b) Sé de muchas que en este mismo momento lo estarán pasando mal, esperando, mitigando, dominadas por un sentimiento que sólo se paga con la desgracia.

A presenza dunha preposición no то antes do infinitivo flexionado proba que non se trata dun verdadeiro tempo verbal ${ }^{16}$. Este exemplo denota que estamos perante unha categoría morfolóxica híbrida, pois o infinitivo flexionado (e tamén, nalgúns casos concretos, a forma non flexionada) ten en simultáneo propiedades nominais e verbais. No caso en análise a tradutora optou por traducir o infinitivo flexionado por un substantivo.

Os tres casos rexistrados no corpus traen á tona unha vella cuestión das gramáticas da maioría da linguas románicas: a coexistencia no infinitivo de propiedades verbais e nominais, frecuentemente, en simultáneo. Trátase, pois, dunha «categoría híbrida» (Real Academia Española, 2009: 1963). Ocorre que hai infinitivos que teñen máis trazos en común cos substantivos, é o que na máis recente gramática editada pela RAE se denomina «infinitivos nominales» (Real Academia Española, 2009: 1967). Eses infinitivos nominais subdivídense en dúas categorías: os infinitivos nominais de natureza léxica e, por outro lado, os de natureza sintáctica (Real Academia Española, 2009: 1967). Os primeiros admiten o plural e os segundos non admiten o plural, pero si «admiten artículos indefinidos y adjetivos, entre otras pautas características de los contextos nominais» (Real Academia Española, 2009: 1967). Por outro lado están os infinitivos verbais, con características que os aproximan ás formas finitas dos verbos, pero nótese que os infinitivos carecen do morfema tempo, o que na práctica supón que, polo xeral, só apareza en oracións subordinadas ${ }^{17}$.

16 No exemplo que acabamos de ver, no TO (6a) a presenza dunha preposición antes do infinitivo flexionado é a proba de que non se trata dun verdadeiro tempo verbal, pois os verbos que desempeñan a función de núcleo do predicado nunca van precedidos de preposición. Este exemplo denota que estamos perante unha categoría morfolóxica híbrida, pois o infinitivo flexionado (e tamén, nalgúns casos concretos, a forma non flexionada) ten en simultáneo propiedades nominais e verbais. No caso en análise, a tradutora optou por traducir o infinitivo flexionado por un substantivo; nótese que no TT tamén é necesaria unha preposición para introducir o sintagma nominal cuxo núcleo é o substantivo.

17 «Esta combinación excepcional para las especificaciones verbales de persona y tiempo encuentra reflejo en la naturaleza, asimismo excepcional, de las cláusulas a que dan lugar, a las que cabe definir al tiempo como completas y defectivas: completas porque, en contraposición a lo que generalmente ocurre en el caso de las cláusulas con infinitivos no flexionados, las cláusulas con infinitivos flexionados (en adelante, CIF) pueden incorporar formalmente todo el complejo argumental propio del verbo, incluido un sujeto; defectivas porque, ahora a semejanza de aquellas cláusulas, no pueden en general ser usadas más que en contextos subordinados. Las dos características se encuentran en realidad íntimamente relacionadas: las CIF no consiguen en general funcionar autónomamente por su incapacidad para sancionar por sí solas formalmente al sujeto y 
Estas palabras revelan a complexidade e orixinalidade inherente ao infinitivo flexionado e axudan a explicar o despregue de recursos que a tradutora tivo que buscar para trasladar ao castelán a riqueza de matices que ofrece o infinitivo flexionado en portugués.

\subsection{Transposición tipo 4 infinitivo flexionado $\rightarrow$ verbo no indicativo:}

Os casos en que aparece no тт un tempo no indicativo corresponden a infinitivos flexionados que funcionan de forma moi semellante aos verbos finitos. En catro casos (frases 5, 15, 34 e 38 do anexo) encontramos no то o infinitivo flexionado composto. A forma composta do infinitivo achega información sobre o aspecto que normalmente non se atopa nas formas simples nin no infinitivo non flexionado, salvo que adveña do propio significado do verbo. No caso do infinitivo flexionado composto, esa información aspectual é achegada pelo verbo ter e, en rexistros máis formais do idioma, por haver. Que a tradutora recorrese a unha forma finita demostra que o infinitivo flexionado composto comparte máis características coas formas finitas que coas non finitas, e é considerado polas gramáticas unha forma non finita.

TO

Contou-me um judeu meu amigo que havia em Lisboa três prédios de que ele tinha notícia, os quais se achavam abandonados depois de algum tempo de terem ganhado fama de serem habitados por almas do outro mundo.
TT

$\rightarrow \quad \begin{aligned} & \text {-Un judío amigo mío -continuó } \\ & \text { impasible- me contó que él sabía } \\ & \text { de tres casas en Lisboa que estaban } \\ & \text { deshabitadas y la gente se negaba } \\ & \text { a vivir en ellas porque decían que } \\ & \text { tenían fantasmas. }\end{aligned}$

Con todo, hai tamén infinitivos flexionados simples que foron traducidos por un verbo no indicativo (frases 16, 22, 28 e 30), o que na nosa opinión indica que, aínda que non teñan morfema de tempo, teñen característica que os achegan ás formas verbais finitas:

\footnotetext{
constituirse así como una estructura argumental completa. Desde los años ochenta del siglo XX, la gramática generativa explica esta formalidad como un aspecto particular de la llamada «Teoría del Caso» (Chomsky 1981), que concretamente establece que el sintagma sujeto resulta legitimado por la concordancia verbal (Conc) cuando ésta es activada a tal efecto por el tiempo (T)» (Lorenzo, 2015: 42).
} 
TO

(7a) Todos estavam profundamente apiedados. A velhos marinheiros, que tinham naufragado no mar da India e dobrado o Cabo, eu vi saltarem as lágrimas...

\section{TT}

(7b) Todo el mundo se mostraba hondamente consternado; incluso marineros viejos, que habían doblado El Cabo y sufrido naufragios en el mar de la India, tenían lágrimas en los ojos.

\subsection{Transposición tipo 5 infinitivo flexionado $\rightarrow$ infinitivo:}

Esta transposición é a mais produtiva no corpus obxecto da nosa análise:

\begin{tabular}{|c|c|c|}
\hline TO & & TT \\
\hline $\begin{array}{l}\text { Os criminosos, que tinham propinado } \\
\text { ópio à sua vítima com o intuito de } \\
\text { (8a) a roubarem, encontram iludido } \\
\text { este projeto com o desaparecimento } \\
\text { das notas que lhe supunham na } \\
\text { algibeira. Nesta conjetura sobrevêm- } \\
\text { lhes um recurso extremo: procurar } \\
\text { um médico que não possa denunciar } \\
\text { o crime, mostrar-lhe o ópio, e (9a) } \\
\text { quererem por esta prova de zelo, } \\
\text { de solicitude, de confiança na sua } \\
\text { inocência, afastar de si a presunção } \\
\text { do crime, e criar as dificuldades de } \\
\text { um mistério! }\end{array}$ & 89 & $\begin{array}{l}\text { Puede ser que si, según se } \\
\text { desprende de lo que acabo de oír, } \\
\text { le dieron opio con intención de } \\
\text { (8b) robarle y luego se sintieron } \\
\text { defraudados al no encontrarle el } \\
\text { dinero..., se les ocurriera el recurso } \\
\text { de buscar a un médico al cual } \\
\text { mostrar el opio y ante quien (9b) } \\
\text { alardear de inocencia y celo, y } \\
\text { así, mediante esta coartada, urdir } \\
\text { un enigma y desviar posibles } \\
\text { sospechas. }\end{array}$ \\
\hline
\end{tabular}

Esta é a solución máis frecuente encontrada pola tradutora. Na maioría dos casos estamos perante infinitivos flexionados que en portugués admitirían tamén a forma non flexionada sen alterar substancialmente o significado do texto como nos exemplos anteriores ( 8 a e 9 a), onde poderiamos substituír as formas flexionadas que alí aparecen por «roubar» e «querer» sen que se produza unha mudanza de significado ou unha oración agramatical.

\subsection{Transposición tipo 6 infinitivo flexionado $\rightarrow$ adxectivo:}

Trátase dun caso particular no que as funcións do infinitivo no тo son levadas a cabo por un adxectivo (derivado dun participio). Neste caso, o adxectivo ten a función de atributo diverxendo da estrutura sintáctica de то pero mantendo o significado. 
TO

Aquele amparo superior, aquele apoio sólido e protetor, que todo o espírito procura no mundo, e que uns acham na família, outros na ciência, outros na arte, tu parece (10a) quereres encontrá-lo somente na paixão, e não sei se isso é justo, se isso é realizável!

\section{TT}

Ese amparo supremo, ese apoyo firme y sólido que todo espíritu busca por el mundo y que unos lo encuentran en la familia, otros en la ciencia y otros en el arte, tú pareces (10b) empeñada en encontrarlo exclusivamente en la pasión y no sé si esto es justo ni asequible.

\subsection{Transposición tipo 7 infinitivo flexionado $\rightarrow \emptyset$}

Hai un exemplo en que non atopamos unha correspondencia clara entre o infinitivo flexionado e un elemento do тт:

TO

Seguiam-se as linhas em que se contava o encontro que teve comigo, as quais linhas elimino por se (11) referirem a sucessos que eu mesmo narrei e que V. Sr. redator, já conhece.

A. M. C.

\section{TT}

$\rightarrow$

A continuación de lo transcrito la condesa refiere el encuentro que tuvo conmigo, pero estas líneas, señor director, me ha parecido mejor omitirlas; juzgo innecesario volver sobre algo que ya conoce usted a través de mis revelaciones anteriores.

A.M.C.

Neste exemplo as funcións do infinitivo flexionado dilúense en varios elementos do Tт, e non hai un elemento que asuma con clareza a función daquel. A tradutora optou por reelaborar no тT o contido do To sen que se poida identificar de forma clara cal a forma que substitúe o infinitivo flexionado do то. 


\subsection{Transposición tipo 8 infinitivo flexionado $\rightarrow$ perífrase verbal}

\begin{tabular}{|c|c|c|}
\hline TO & & TT \\
\hline $\begin{array}{l}\text { No momento de (12a) partirmos, o } \\
\text { que ia guiar bateu na vidraça e pediu } \\
\text { um charuto. Passaram-lhe para fora } \\
\text { uma charuteira de palha de Java. }\end{array}$ & $\rightarrow$ & $\begin{array}{l}\text { Cuando ya (12b) estábamos a } \\
\text { punto de arrancar, el que iba al } \\
\text { pescante llamó por estos cristales } \\
\text { y pidió un cigarro; le pasaron una } \\
\text { cigarrera de paja de Java. }\end{array}$ \\
\hline
\end{tabular}

O infinitivo flexionado do to é trasposto pola perífrase aspectual de infinitivo (perífrase incoativa) e mantense dese xeito no тт o sentido do то.

\subsection{Resumo dos tipos de transposición}

A seguinte táboa amosa a distribución conforme a porcentaxe de cada un dos tipos de transposición documentados na obra obxecto de estudo:

\section{TÁBOA 7: DistribuCIÓNS dos TIPOS DE TRANSPOSICIÓN N'O MISTÉRIO DA ESTRADA DE SINTRA EN PORCENTAXE.}

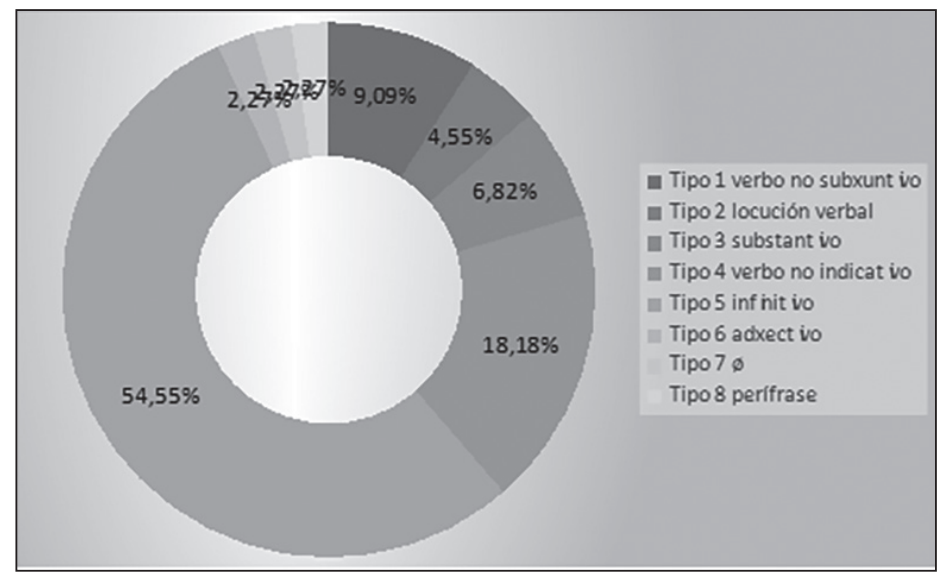

$\mathrm{Na}$ táboa anterior obsérvanse os datos en porcentaxe. Na táboa seguinte damos os mesmos resultados da distribución por tipos de transposición en números absolutos: 
TÁBOA 8: DistribUCIÓNS DOS TIPOS DE TRANSPOSICIÓN N'O MISTÉRIO DA ESTRADA DE SINTRA EN TERMOS ABSOLUTOS.

\begin{tabular}{|l|l|}
\hline Tipo de transposición & N. $^{\text {o }}$ resultados \\
\hline Tipo 1 verbo no subxuntivo & 4 \\
\hline Tipo 2 locución verbal & 2 \\
\hline Tipo 3 substantivo & 3 \\
\hline Tipo 4 verbo no indicativo & 8 \\
\hline Tipo 5 infinitivo & 24 \\
\hline Tipo 6 adxectivo & 1 \\
\hline Tipo $7 \varnothing$ & 1 \\
\hline Tipo 8 perífrase verbal & 1 \\
\hline
\end{tabular}

Dos datos expostos nas táboas anteriores pódese concluír que hai unha diversificación considerable de recursos en castelán para desempeñar as funcións que en portugués soe realizar o infinitivo flexionado.

Por outra parte, no то obsérvase que os infinitivos flexionados constitúen xeralmente oracións subordinadas de diversos tipos e hai tamén algúns casos en que o infinitivo constitúe un grupo nominal. Atopamos oracións subordinadas substantivas e adverbiais (concesivas, temporais, causais, condicionais e causais). Non entraremos en detalle a describir e analizar sintacticamente as oracións, porque extravasa o ámbito do noso estudo que se centra na transferencia morfolóxica, pero debido á estreita relación entre a morfoloxía e a sintaxe temos que facer algunhas consideracións que nos parecen importantes.

As oracións nо то son, polo xeral, longas e cunha estrutura bastante complexa, o que nalgúns casos dificulta a análise. Non obstante, salvo en contadas excepcións, a tradutora respectou a estrutura e as dependencias sintácticas que había no то. Só en casos puntuais observamos que o texto é modificado nalgunhas partes ou hai mudanzas na posición dalgúns elementos para tornar os textos máis naturais en castelán, como vemos no seguinte exemplo: 


\begin{tabular}{|c|c|c|c|c|}
\hline N. ${ }^{\circ}$ & Inf. flexionado по то & Páx. & no TT & Páx. \\
\hline 1 & $\begin{array}{l}\text { Sem eu bem poder a esse } \\
\text { tempo explicar porquê, não } \\
\text { me parecia também que as } \\
\text { pessoas que nos rodeavam } \\
\text { projectassem um roubo, } \\
\text { menos ainda um homicídio. }\end{array}$ & 22 & $\begin{array}{l}\text { Tampoco me daba la } \\
\text { impresión de que la } \\
\text { conducta de aquella gente } \\
\text { denotara móviles de robo } \\
\text { y menos de homicidio, } \\
\text { aunque en aquel momento } \\
\text { no hubiera podido } \\
\text { denotar el porqué de esta } \\
\text { intuición }\end{array}$ & 17 \\
\hline
\end{tabular}

Verificouse tamén que abondan, entre as subordinadas, as adverbiais temporais e as finais. Nótese que o infinitivo flexionado é, en portugués, o núcleo de oracións subordinadas ou de grupos nominais e só en circunstancias moi especiais pode ser o núcleo dunha oración principal. Isto é debido, na nosa opinión, ao feito de que tanto en español como en portugués as formas nominais do verbo (infinitivo, xerundio e participio) carecen do morfema de tempo. O morfema tempo é un morfema que ten un papel fundamental á hora de seleccionar o suxeito da oración principal. No obstante, no infinitivo flexionado establécese esa concordancia normalmente en oracións subordinadas, se ben que, por veces, até funciona como núcleo de oracións principais. Non obstante, observamos que en xeral as oracións de infinitivo son usadas en contextos subordinados.

Eses contextos mantéñense xeralmente nas transposicións que realizou a tradutora. Como vimos, só as de tipo 5 poderían ter dado lugar a oracións principais, o que non foi o caso, pois a tendencia é manter o mesmo tipo de oración que había nо то, como no seguinte exemplo:

\begin{tabular}{|c|c|c|c|c|}
\hline $\begin{array}{l}\mathrm{N}^{\circ} \\
\text { result. }\end{array}$ & Inf. flexionado no то & Páx. & no TT & Páx. \\
\hline 5 & $\begin{array}{l}\text { Em seguida rangeu uma } \\
\text { fechadura e transpusemos } \\
\text { o limiar de uma porta, que } \\
\text { foi outra vez fechada à } \\
\text { chave depois de havermos } \\
\text { entrado. }\end{array}$ & 32 & $\begin{array}{l}\text { Luego chirrió una } \\
\text { cerradura y transpusimos } \\
\text { el umbral de una puerta que } \\
\text { en cuanto entramos fue } \\
\text { cerrada con llave. }\end{array}$ & 27 \\
\hline
\end{tabular}

No exemplo anterior observamos que no то o infinitivo flexionado é o núcleo dunha oración subordinada adverbial de tempo e, no тт, o infinitivo flexionado é substituído polo pretérito do indicativo pero mantense a oración subordinada adverbial de tempo. 


\section{IX.- CONCLUSIÓNS}

Ao observarmos os datos das táboas 7 e 8 vemos que o recurso ao infinitivo castelán é o máis frecuente de todos os empregados pola tradutora para traducir o infinitivo flexionado na versión castelá d'O Mistério da Estrada de Sintra. Na maioría deses casos en que no español se recorre ao infinitivo en portugués pódese substituír tamén pola forma non flexionada do infinitivo sen que se produza unha alteración de significado ou se produza algún tipo de ambigüidade (p. ex. na frase 41 do Anexo, Há outras exigências, que hoje não sentes chamarem dentro de ti, $[. .$.$] poderíamos pór en portugués «chamar»). Se ben é certo$ que nalgúns casos é unha cuestión de énfase ou préndese, o emprego da forma flexionada, cun uso máis coidado da lingua. Isto confirma o que sinalan autores xa aquí referidos como Celso Cunha e Lindley Cintra para quen o infinitivo flexionado ten, sobre todo, unha función estilística (Cunha, 2002: 487).

Outra conclusión á que chegamos despois realizarmos este traballo é que o homomorfismo existente na $1 \mathrm{p}$ e $3 \mathrm{p}$ do infinitivo flexionado e a forma non flexionada supón que na primeira e terceira persoa esta distinción sexa, na práctica, pouco operativa, a excepción prodúcese cando o infinitivo flexionado está acompañado de forma explícita por un suxeito (como nos bi-textos ou frases 1 («sem eu bem poder a esse tempo explicar» e 6 «alguém tocar na porta» do Anexo).

Verificamos que a categoría gramatical «infinitivo» é ben máis complexa do que semella a simples vista. Esa complexidade préndese, como xa vimos, co feito de ser unha categoría híbrida que posúe características propias tanto do substantivo como do verbo. Ademais, uns infinitivos parecen estar máis próximos ao substantivo e desempeñan as funcións típicas daquel na oración, mentres que outros infinitivos teñen un funcionamento semellante ao dos verbos aínda que non posúen o morfema de tempo. Vimos tamén que este panorama se complica aínda máis en portugués, lingua que conta cunha forma non flexionada do infinitivo e outra forma que admite desinencia de número e persoa.

Esa complexidade ten reflexos evidentes á hora de traducirmos o infinitivo flexionado. Como vimos, hai, polo menos, oito maneiras ou tipos de transposición para traducirmos o infinitivo flexionado ao castelán. Estas oito categorías ou tipoloxías son bastante abranguentes e poderíamos, por exemplo no caso do tipo 5, subdividir esta categoría en polo menos dúas subclases, a saber: infinitivos nominais e verbais. Por súa vez, a Nueva Gramática del Español subdivide os infinitivos nominais en dúas subclases.

Observouse tamén como a forma composta do infinitivo achega información sobre o aspecto que non se atopa nas formas simples nin no infinitivo non flexionado. Esta información aspectual é achegada pelo verbo ter, e en rexistros máis formais do idioma por haver, que expresa a noción de perfectividade patente no infinitivo flexionado composto.

As estreitas relacións entre o plano lingüístico da morfoloxía e o da sintaxe, tornan difícil xebrar de xeito taxativo un e outro. Aínda que queda fóra do ámbito proposto para o presente traballo, sentimos a necesidade de facer refe- 
rencia a algúns aspectos da sintaxe, pero por limitacións de espazo non afondamos máis nese eido.

Achamos que Carmen Martín Gaite conseguiu con éxito resolver o problema da tradución deste aspecto particular da gramática do portugués na versión d'O Mistério da Estrada de Sintra que nos legou. Temos a noción de que o catálogo de recursos que aquí se expós non é algo pechado, haberá certamente outros recursos que nun corpus tan pequeno como o que aquí empregamos non aparecen. Dito doutro xeito, non estamos perante unha clasificación pechada, pois nun corpus máis amplo atopariamos certamente outros xeitos de traducir o infinitivo flexionado. Ademais, en moitos casos a tradutora escolleu a opción que lle pareceu máis axeitada nese fragmento entre un abanico de posibilidades máis ou menos amplo segundo os casos.

Con todo, queda aquí o rexistro dalgunhas das opcións ao noso dispor e, máis importante que iso, desenvolvemos os procedementos e as ferramentas de análise, máis ou menos rudimentarios, que nos permitirán analizar ese fenómeno de forma axeitada cando esteamos diante dun infinitivo flexionado.

$\mathrm{O}$ aspecto analizado no presente estudo confirma, na nosa opinión, a idea de Toury (quen estudou as traducións do alemán ao hebreo entre 1930 e 1945 e do inglés ao hebreo en varios períodos) de que os tradutores non están moi preocupados coa adhesión ás normas do to e si o están, en troques, por ir ao encontro das normas do sistema onde se vai encaixar o тт. A idea de que a equivalencia entre о то е о тт non pode ser total parécenos evidente tendo en conta os datos manexados no noso estudo. Nese sentido coidamos, con Moya, que Toury «apuesta por una equivalencia traslatoria más compleja donde las interferencias del sistema meta desempeñan un papel muy importante: las opciones del traductor responden a situaciones concretas y no siempre elige siguiendo el modelo del то». Aínda que a teoría de Toury presenta algúns aspectos cuestionábeis, ten a virtude de pór o acento no proceso e no resultado, e abandona análises utópicas e prescritivas do fenómeno da tradución e céntrase en describir as traducións concretas.

Para este autor a equivalencia non é un ideal abstracto. Por iso, non debemos alimentar utopías como a da tradución correcta. Haberá, iso si, traducións con graos diversos de equivalencia, e traducións con maior ou menor aceptación na cultura meta.

Para concluír, hai que referir que este traballo nos permitiu reflectir sobre a importancia do uso da nosa propia lingua e en particular sobre o emprego do infinitivo flexionado en galego. Usar a nosa lingua sempre que posíbel, aproveitando todos os recursos que o idioma pon a noso dispor e co maior coidado é a mellor forma de honrar as mulleres e os homes que a falaron antes de nós e a mellor herdanza que se pode deixar aos nosos fillos. É este tamén o camiño máis certo para cumprir o desexo de Álvaro Cunqueiro que tamén é o noso: que o idioma de Mendiño conte con mil primaveras máis. 


\section{BIBLIOGRAFÍA}

\section{A) Corpus}

Eça de Queiroz, J.M. + J. D. Ramalho Ortigão (2016) O Mistério da Estrada de Sintra. Porto, Livros do Brasil.

Eça de Queiroz, J.M. + J.D. Ramalho Ortigão (s.d.) O Mistério da Estrada de Sintra. Luso Livros: https://www.luso-livros.net/wp-content/ uploads/2013/05/O-Mist\%C3\%A9rio-da-Estrada-de-Sintra.pdf (marzo 2019)

Eça de Queiroz, J.M. + J.D. Ramalho Ortigão + C. Martín Gaite (trad.) (1983) El misterio de la carretera de Sintra. Barcelona, Bruguera.

\section{B) Bibliografía consultada}

Aguirre Moreno, J.L. + A. Álvarez Lugrís + X. Gómez Guinovart (2002) «Etiquetario morfosintáctico del SLI para corpus de lengua gallega: aplicación al corpus paralelo TECTRA». Procesamiento del Lenguaje Natural, 28, páxs. 23-34.

Ali, Said (s./d.), Gramática secundária da língua portuguesa. São Paulo, Melhoramentos.

Alonso, D. + V. García Yebra (1954) El gallego-leonés de Ancares y su interés para la dialectología portuguesa publicado en Alonso, D. + V. García Yebra (2009) Tres viajes dialectológicos por Ancares. Ponferrada, Instituto de Estudios Bercianos.

Álvarez, R. + X. Xove. (2002) Gramática da lingua galega. Vigo: Galaxia. Álvarez Lugrís, A. (2001) Estilística comparada da traducción: Proposta metodolóxica e aplicación práctica ó estudio do corpus TECTRA de traduccións do inglés ó galego. Vigo: Universidade de Vigo.

Azevedo, A. (1890) O Cortiço. Segundo milheiro. Río de Xaneiro, Garnier.

Bueno García, A. + J. García Medall (Coords.) (1998) La traducción: de la teoría a la práctica. Valladolid, Servicio de Apoyo a la Enseñanza de la Universidad de Valladolid.

Catford, J. C. (1965) Una teoría lingüistica de la traducción: ensayo de lingüística aplicada. Caracas, Universidad Central de Venezuela.

Chomsky, N. (1957) Syntactic Structures. A Haia, Mouton Publishers.

Chomsky, N (1965) Aspects of the Theory of Syntax. Cambridge (Massachusetts), The MIT Press. 
Corpas, P. G (1997) «Grados de equivalencia translémica de las locuciones en inglés y español», 335-341 en R. J. Sola / L. A. Lázaro / J. A. Jáuregui eds.: Actas del XVIII Congreso de AEDEAN (Alcalá de Henares, 15-17 de diciembre de 1994), Servicio de Publicaciones de la Universidad de Alcalá de Henares.

Crystal, D. (2000) Language Death. Cambridge, Cambridge University Press.

Cunha, C. + L. Cintra (2002, 17. a ed.) Nova Gramática do Português Contemporâneo. Lisboa: João Sá da Costa.

Dosil López, B. + X. Riveiro Costa (2004) Dicionario de ortografía da lingua galega. A Coruña, Galinova Editorial.

Even-Zohar, I. (1990) «The Position of Translated Literature within the Literary Polysystem.» Poetics Today, 11:1, páx. 45 a 51.

Feixó Cid, X. (2005) As normas ortográficas e morfolóxicas da lingua galega. Actualización, complementos e desviacións. Vilaboa, Edicións do Cumio.

Ferreira, A. G. + J. Nunes de Figueiredo (2006) Compêndio de Gramática Portuguesa. Porto, Porto Editora.

Fidalgo Enríquez, F. J. (2011) “¿Infinitivo personal en español?”, Actas del IV Congreso sobre la Enseñanza del Español en Portugal, páx. 60 a 79 [en rede], consulta: http://www.mecd.gob.es/portugal/dms/consejeriasexteriores/portugal/publicaciones/ActasIVCongresoEvora.pdf (marzo 2019)

García Izquierdo, I. (2000) Análisis textual aplicado a la traducción. Valencia, Tirant lo Blanch.

Gavilanes, J. L. + A. Apolinário (Eds.) (2000) Historia de la literatura portuguesa. Madrid, Cátedra.

Gondar, F. G. (1978) O infinitivo conxugado en galego, Anexo 13 de Verba, Universidade de Santiago de Compostela.

González Couso, D. (2009) «Carmen Martín Gaite y su geografía literaria», Espéculo. Revista de estudios literarios. Universidad Complutense de Madrid [en rede], https://ciberduvidas.iscte-iul.pt/consultorio/perguntas/o-uso-dosinfinitivos-pessoal-e-impessoal/30627 (marzo 2019)

Hampejs, Z. (1959) «Algúns problemas do infinitivo conjugado no português», Boletim de Filologia, 18, páxs. 177-194.

Hampejs, Z. (1959/1960) «Nota sintáctico-estilística sobre o infinitivo flexionado português», Revista Brasileira de Filologia, 5, páxs. 115-118.

Holmes, J. S. (1978a1988). «Translation Theory, Translation Theories, Translation Studies and the Translator», en Horguelin (ed.) (1978), páxs. 5561. Editado en Holmes (1988), páxs. 9299.

Holmes, J. S. (1988) Translated! Papers on Literary Translation and Translation Studies. Amsterdam/Atlanta (GA), Editions Rodopi B.V. 
Huber, J. (2006) Gramática do Português Antigo. Lisboa: Fundação Calouste Gulbenkian.

Instituto Cervantes (s.d.) «Bibliografía de Carmen Martín Gaite», Bibliotecas y Documentación [en rede], consulta: 03/05/2017. Publicación dispoñíbel en: http://www.cervantes.es/imagenes/File/martin_gaite_biblio.pdf (marzo 2019)

Linguakitbeta (s.d.) etiquetador morfosintáctico de português. [en rede], consulta: 12/05/2017. Ferramenta dispoñíbel en: https://linguakit.com/pt/ etiquetador-morfossintatico (marzo 2019)

Lorenzo González, G. (2016) «¿Por qué no en asturiano? El infinitivo flexionado como «apomorfia negativa» de la lengua asturiana», Lletres Asturianes: http://www.academiadelallingua.com/lletresasturianes/ pdf/1460020879Art\%C3\%ADculu\%202-Guillermo\%20Lorenzo\%20 Gonz\%C3\%A1lez-Por\%20qu\%C3\%A9\%20no\%20en\%20asturiano.\%20 El\%20infinitivo\%20flexionado\%20como\%20apomorfia\%20negativa\%20 de\%201a\%20lengua\%20asturiana.pdf (marzo 2019)

Matte Bon, F. (2009) Gramática comunicativa del español. Tomo I. Madrid: Edelsa, 12. ${ }^{a}$ reimpresión, 1. ${ }^{a}$ edición: 1992. Mattos e Silva, Rosa Virgínia (1989) Estruturas Trecentista. Elementos para uma Gramática do Português Arcaico. Lisboa, INCM.

Maurer J.R., T. H. (1968) O infinitivo flexionado português. São Paulo, Cia Editora Nacional-USP.

Moya, V. (2004) La selva de la traducción. Teorías traductológicas contemporáneas. Madrid, Cátedra.

Nancy D. (1981) Language Death: the life cycle of a Scottish Gaelic dialect. Filadelfia, University of Philadelphia Press.

Neves, M. H. de Moura (2000) Gramática de Usos do Português. São Paulo. Editora UNESP.

Newmark, P. (2006) Manual de traducción. Madrid, Cátedra.

Piel, J.-M. (1989) «A Flexão verbal do português (Estudo de morfologia histórica)», en Estudos de Linguística Histórica Galego-Portuguesa, páx. 213 a 244. Lisboa, INCM. Publicado orixinalmente en 1944.

Rabadán, R. (1991) Equivalencia y traducción. Problemática de la equivalencia translémica inglés-español. León, Universidade de León.

Real Academia Española (2009) Nueva gramática de la lengua española. [vol. II, sintaxis], Madrid: Real Academia Española / Asociación de Academias de la Lengua Española / Espasa Libros.

Real Academia Española (2010) Nueva gramática de la lengua española. [Manual], Madrid, Real Academia Española / Asociación de Academias de la Lengua Española / Espasa Libros. 
Real Academia Española (2014) Diccionario de la lengua española. (23.a ed.) [en rede], http://www.rae.es/rae.html (marzo 2019)

Sala, M. (1998) Lenguas en contacto. Madrid, Gredos.

Teyssier, P. (1997) História da Língua Portuguesa. Lisboa, Livraria Sá da Costa Editora.

Toury, G. (1980) In Search of a Theory of Translation. Tel Aviv, Porter Institute.

Toury, G. (1995) Descriptive Translation Studies -and Beyond. Benjamins Translation Library, vol. ${ }^{\circ}$ 4. Amsterdam/Filadelfía, John Benjamins Publishing Company.

Toury, G. (1986) «Monitoring Discourse Transfer: A TestCase for a Developmental Model of Translation», en House \& BlumKulka (eds.), páx. 7994.

Vilela, M. (supervisión) + Clara Amorim + Catarina Sousa (2009) Gramática da Lingua Portuguesa. Porto, Areal.

VV. AA. (2003) Alinhamento e etiquetagem de corpora paralelos no CLUVI (Corpus Linguístico da Universidade de Vigo), en Actas do Workshop CP3A 2003, Corpora Paralelos: Aplicações e Algoritmos Associados, Braga, Universidade do Minho, Eds: José João Almeida, páxs. 33-47.

VV. AA. (2003) Gramática da Língua Portuguesa. Lisboa, Editorial Caminho.

\section{Abreviaturas empregadas}

adx.: adxectivo

art.: artigo

gal.: galego

indf.: indefinido

INF: infinitivo non flexionado

INFC: infinitivo non flexionado composto

IF: infinitivo flexionado

IFC: infinitivo flexionado composto

S: substantivo

SN: Sintagma Nominal

SV: Sintagma Verbal

VI: verbo en indicativo

VS: verbo en subxuntivo

To: texto orixinal ou de partida 
тт: texto traducido ou de chegada

1p: primeira persoa do singular

$2 \mathrm{p}$ : segunda persoa do singular

3p: terceira persoa do singular

$4 \mathrm{p}$ : primeira persoa do plural

$5 \mathrm{p}$ : segunda persoa do plural

6p: terceira persoa do plural

loc. verbal: locución verbal

V verbo 